\title{
ADSORPTION OF SULFUR HEXAFLUORIDE ONTO CRUSHED TUFFS FROM THE YUCCA MOUNTAIN AREA, NYE COUNTY, NEVADA
}

by Gordon W. Rattray, Robert G. Striegl, and In C. Yang

\section{U.S. GEOLOGICAL SURVEY}

Water-Resources Investigations Report 95-4057

Prepared in cooperation with the

NEVADA OPERATIONS OFFICE,

U.S. DEPARTMENT OF ENERGY under

Interagency Agreement DE-Al08-92NV10874

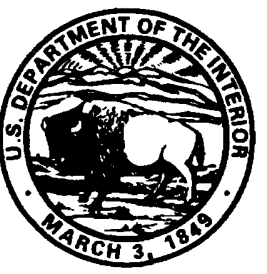




\section{U.S. DEPARTMENT OF THE INTERIOR \\ BRUCE BABBITT, Secretary}

U.S. GEOLOGICAL SURVEY

Gordon P. Eaton, Director

The use of trade, product, industry, or firm names is for descriptive purposes only and does not imply endorsement by the U.S. Government.

For additional information write to:

Chief, Earth Science Investigations Program Yucca Mountain Project Branch U.S. Geological Survey Box 25046, MS 421 Denver Federal Center Denver, CO 80225
Copies of this report can be purchased from: U.S. Geological Survey Earth Science Information Center Open-File Reports Section Box 25286, MS 517

Denver Federal Center Denver, CO 80225 


\section{CONTENTS}

Abstract

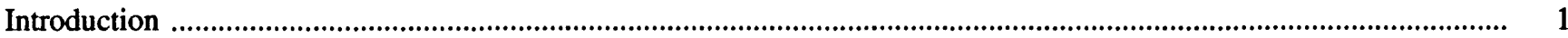

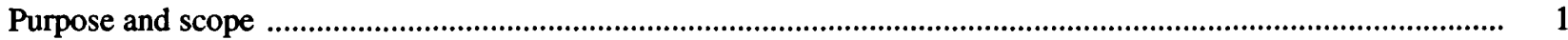

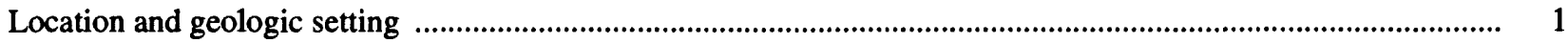

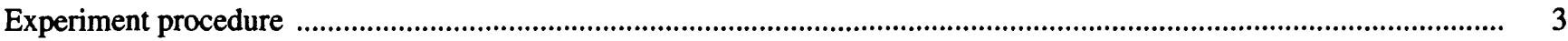

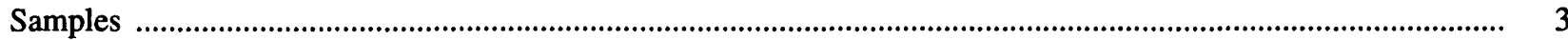

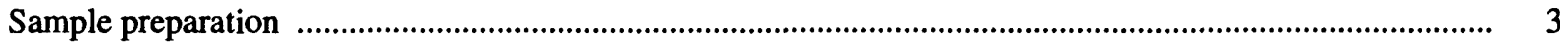

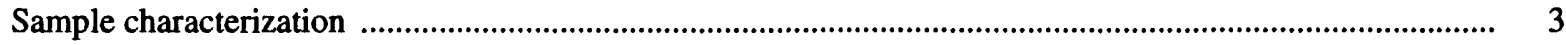

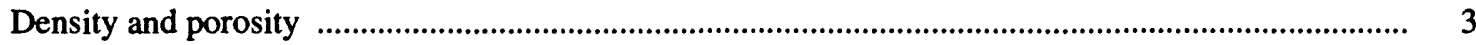

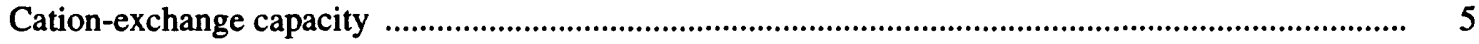

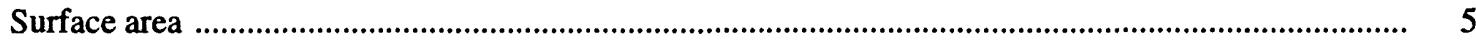

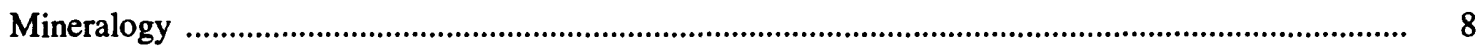

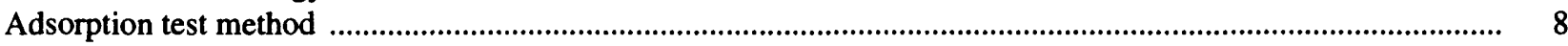

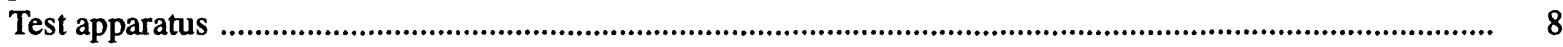

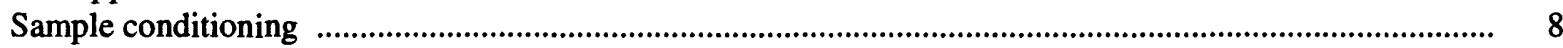

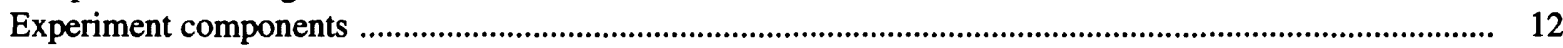

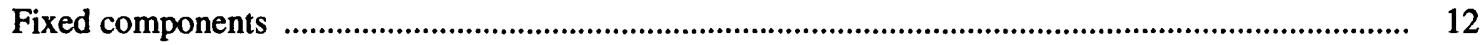

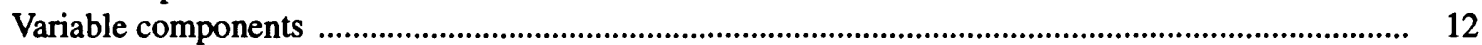

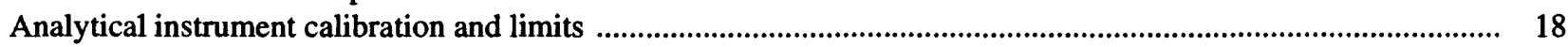

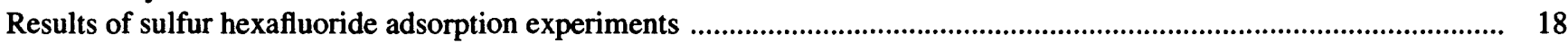

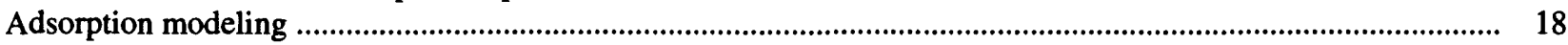

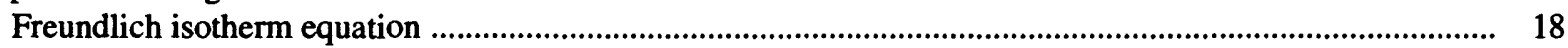

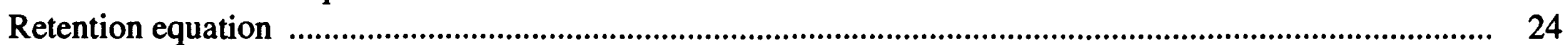

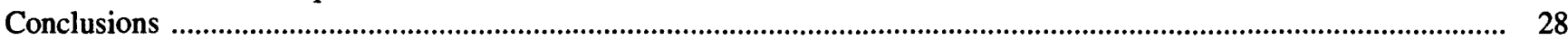

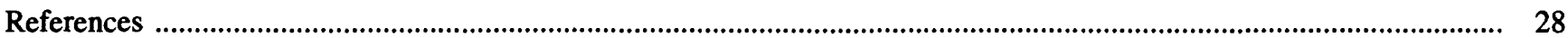

\section{FIGURES}

1. Location of drill holes UE-25 UZ \#4 and UE-25 UZ \#5, and nearby geographic features in southern Nevada

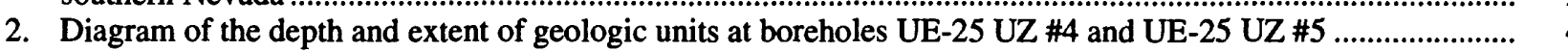

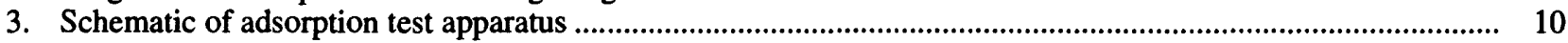

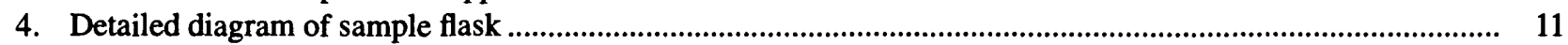

5-12. Graphs showing:

5. Adsorption of sulfur hexafluoride $\left(\mathrm{SF}_{6}\right)$ onto dry and wet bedded tuff $(\mathrm{BT})$, as a function of time, with an initial concentration of sulfur hexafluoride in the flask of $1.94 \mathrm{ppmv}$

6. Adsorption of sulfur hexafluoride $\left(\mathrm{SF}_{6}\right)$ onto Pah Canyon Tuff $(\mathrm{PCT})$ and Yucca Mountain Tuff (YMT), as a function of time, with an initial concentration of sulfur hexafluoride in the flask of $1.94 \mathrm{ppmv}$

7. Adsorption isotherms for bedded tuff (BT) and Topopah Spring Tuff, UE-25 UZ \#4 (TST4) ................ 19

8. Adsorption isotherms for Yucca Mountain Tuff (YMT), Topopah Spring Tuff, UE-25 UZ \#5 (TST5), and clinoptilolite

9. Adsoprtion isotherms for Tiva Canyon Tuff (TCT), Pah Canyon Tuff (PCT), and gypsum cement (GC). 4 11

10. Moles of sulfur hexafluoride adsorbed, per square meter of tuff, as a function of the partial pressure

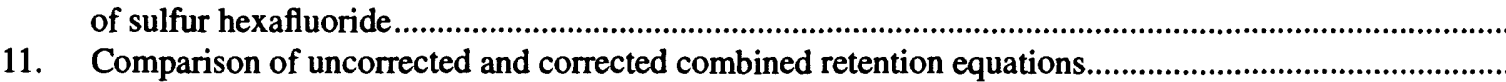

12. Correlation of equilibrium constant $\left(\mathrm{K}_{\mathrm{d}}\right)$ and surface area with the percent of zeolite in the tuffs............. 


\section{TABLES}

1. Sample collection depth and degree of welding of tuff samples

2. Densities, porosities, and cation-exchange capacities for crushed tuffs, gypsum cement, and clinoptilolite............ 6

3. Surface-area analyses $\left(\mathrm{m}^{2} / \mathrm{g}\right)$ of crushed tuffs, gypsum cement, clinoptilolite, and kaolinite .................................... 7

4. Mineralogical analyses (weight percent) of crushed tuffs, gypsum cement, and clinoptilolite ............................... 9

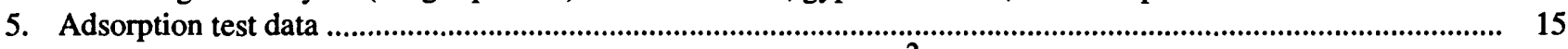

6. Values for constants $\left(N, K_{d} K\right)$, squared correlation coefficients $\left(r^{2}\right)$, and standard error of estimate (SEE) for the Freundlich isotherm equations and the retention equations ........................................................ 23

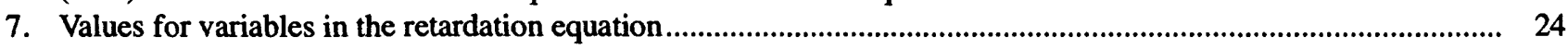

8. Values of variables in the retardation equation using bulk and grain densities (for porosity calculations) of core samples.

9. Predicted adsorption of sulfur hexafluoride ( $\mathrm{pmol}_{\mathrm{SF} 6} / \mathrm{g}_{\text {tuff }}$ ) onto tuffs using the combined and individual

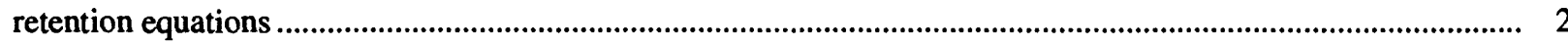

\section{CONVERSION FACTORS}

\begin{tabular}{rll}
\hline Muitiply & By & To obtain \\
\hline & & \\
cubic centimeter per minute $\left(\mathrm{cm}^{3} / \mathrm{min}^{3}\right)$ & 3.661 & cubic inch per second \\
cubic meter $\left(\mathrm{m}^{3}\right)$ & $3.531 \times 10^{1}$ & cubic foot \\
gram per cubic centimeter $\left(\mathrm{g} / \mathrm{cm}^{3}\right)$ & $5.781 \times 10^{-1}$ & ounce per cubic inch \\
kilometer $(\mathrm{km})$ & $6.214 \times 10^{-1}$ & mile \\
meter $(\mathrm{m})$ & 3.281 & foot \\
meter squared per gram $\left(\mathrm{m}^{2} / \mathrm{g}\right)$ & $3.050 \times 10^{2}$ & foot squared per ounce \\
micrometer $(\mu \mathrm{m})$ & $3.937 \times 10^{-5}$ & inch \\
millimeter $(\mathrm{mm})$ & $3.937 \times 10^{-2}$ & inch \\
millipascal $(\mathrm{mPa})$ & $1.450 \times 10^{-7}$ & pound per square inch \\
pascal $(\mathrm{Pa})$ & $1.450 \times 10^{-4}$ & pound per square inch \\
picogram per cubic centimeter $\left(\mathrm{pg} / \mathrm{cm}^{3}\right)$ & $5.781 \times 10^{-13}$ & ounce per cubic inch \\
picomole per gram $(\mathrm{pmol} / \mathrm{g})$ & $2.835 \times 10^{1}$ & picomole per ounce \\
\hline
\end{tabular}

Degree Celsius $\left({ }^{\circ} \mathrm{C}\right)$ may be converted to degree Fahrenheit $\left({ }^{\circ} \mathrm{F}\right)$ by using the following equation:

$$
{ }^{\circ} \mathrm{F}=9 / 5\left({ }^{\circ} \mathrm{C}\right)+32 \text {. }
$$

Kelvin (K) may be converted to degree Celsius $\left({ }^{\circ} \mathrm{C}\right)$ by using the following equation:

$$
{ }^{\circ} \mathrm{C}=\mathrm{K}-273.15 \text {. }
$$




\title{
Adsorption of Sulfur Hexafluoride Onto Crushed Tuffs from the Yucca Mountain Area, Nye County, Nevada
}

\author{
By Gordon W. Rattray, Robert G. Striegl, and In C. Yang
}

\section{Abstract}

A laboratory batch-type testing procedure was developed that provides a simple, rapid, and reproducible method to investigate the adsorptive capabilities of crushed materials for gaseous compounds. Several batch tests were conducted to test crushed samples of tuff, clinoptilolite, and gypsum cement for their retention of sulfur hexafluoride. For each sample tested, the surface area, distribution coefficient, and retention equation were determined. The surface areas of the samples decreased in the following order: Topopah Spring Tuff, UE-25 UZ \#5; bedded tuff; clinoptilolite; Yucca Mountain Tuff; Topopah Spring Tuff, UE-25 UZ \#4; Pah Canyon Tuff; gypsum cement; and Tiva Canyon Tuff. The distribution coefficients show that sulfur hexafluoride is readily adsorbed onto clinoptilolite, bedded tuff, and Topopah Spring Tuff, but that it does not appreciably adsorb onto gypsum cement, Tiva Canyon Tuff, or Pah Canyon Tuff. Retention equations, which were calculated as a function of the surface area of the tuffs, were similar for all but one (Tiva Canyon Tuff) of the tuffs. The similarity of the retention equations demonstrates that the surface area of a tuff is a good indicator of the sorptive capability of the tuff. The distribution coefficients and the surface areas of the tuffs show a correlation with the amount of zeolite in the tuff, providing evidence that zeolites are the principal mineral controlling the adsorption of sulfur hexafluoride.

\section{INTRODUCTION}

The U.S. Geological Survey (USGS) is conducting investigations to determine the geologic and hydrologic suitability of the Yucca Mountain area, Nye County, Nevada, as a potential site for a mined geologic repository for high-level nuclear wastes. These investigations are being conducted under the auspices of the U.S. Department of Energy, Nevada Operations Office, under Interagency Agreement
DE-AI08-92NV10874, and are part of the Yucca Mountain Site Characterization Project.

Effective utilization of gaseous tracers in geologic materials requires either that the tracer be truly conservative or that its transport properties be known. Although $\mathrm{SF}_{6}$ has previously been used as a gaseous tracer to study the tortuosity and sorption-affected porosity in the unsaturated zone at a low-level nuclear waste disposal site near Barnwell, South Carolina (Kreamer and others, 1988), and is currently being used in unsaturated zone studies at Yucca Mountain, Nevada, the transport properties of $\mathrm{SF}_{6}$ have not been rigorously evaluated.

The main objective of the work described here is to provide a model that accurately predicts the behavior of $\mathrm{SF}_{6}$ in the unsaturated zone of the Yucca Mountain area. Understanding how $\mathrm{SF}_{6}$ interacts with unsaturated zone materials will be helpful in evaluating the effectiveness of $\mathrm{SF}_{6}$ as a gas tracer for ongoing gascirculation studies, air-permeability testing, and drydrilling operations at Yucca Mountain.

\section{Purpose and Scope}

This report presents the results of batch experiments testing the adsorption of a gaseous tracer, sulfur hexafluoride $\left(\mathrm{SF}_{6}\right)$, onto (1) crushed tuffs; (2) clinoptilolite, a principal zeolite mineral found in the tuffs; and (3) gypsum cement, a grout material used to stem instrumented boreholes at Yucca Mountain.

\section{Location and Geologic Setting}

Yucca Mountain is in Nye County, Nevada, approximately $145 \mathrm{~km}$ northwest of Las Vegas, on the Nevada Test Site (fig. 1). The Yucca Mountain area is underlain by a sequence of Miocene ash-flow tuffs that are separated by ash-fall bedded tuff. The eastern side of the mountain is dissected by five northwest-trending washes underlain by zones of right-lateral strike-slip faults (Scott and Bonk, 1984). 


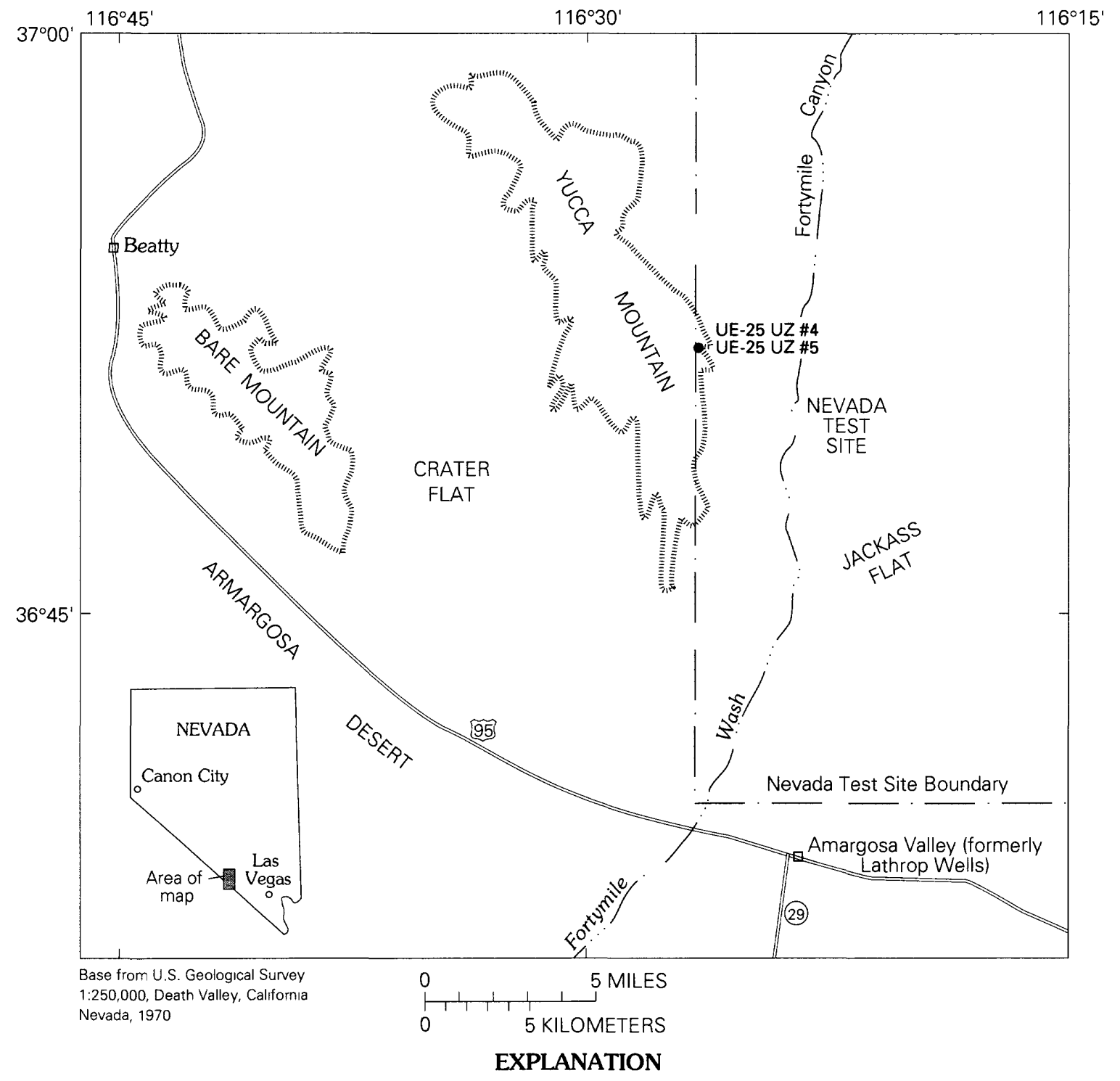

- DRILL HOLES AND IDENTIFICATION

Figure 1. Location of drill holes UE-25 UZ \#4 and UE-25 UZ \#5, and nearby geographic features in southern Nevada. 
Test holes UE-25 UZ \#4 and UE-25 UZ \#5 (hereinafter called UZA and UZ5) are located in Pagany Wash on the eastern side of Yucca Mountain. These holes were drilled to a depth of about $110 \mathrm{~m}$ into the unsaturated Paintbrush Group (Sawyer and others, 1994). The members of the Paintbrush Group penetrated are, in descending order, the Tiva Canyon Tuff, Yucca Mountain Tuff, Pah Canyon Tuff, and Topopah Spring Tuff (Yang, 1992; Loskot and Hammermeister, 1992). The stratigraphy and lithology of the geologic units penetrated at UZA and UZ5 are shown in fig. 2 .

\section{EXPERIMENT PROCEDURE}

The adsorption experiment consisted of three general elements: selecting, preparing, and characterizing the samples; the adsorption test method; and the analytical instrument calibration and $\mathrm{SF}_{6}$ detection limits.

\section{Samples}

The tuffs used in the adsorption tests, except for the Tiva Canyon Tuff, were prepared from core samples obtained from UZ4 and UZ5. The sample from the Tiva Canyon Tuff was prepared from outcrop samples collected on top of Yucca Mountain. The core samples underwent triaxial-compression extraction of pore water before use for adsorption testing. Collection and preparation methods of cores for pore-water extraction are detailed in Yang and others (1988). The experiment samples included a representative from each tuff unit of the Paintbrush Group (table 1). With the exception of the Topopah Spring Tuff, the core intervals (or outcrop samples) from each tuff unit were combined to form one sample. In order to observe the change in sorptive capacity between a welded and nonwelded sample from the same tuff unit, the Topopah Spring Tuff was divided into two samples: one sample contained densely welded core from the UZA core intervals, and the second sample consisted of nonwelded core from the UZ5 core intervals. A sample of clinoptilolite, a major mineral phase of many of the tuffs found at Yucca Mountain, was provided by Lewis-Russ (1990). A sample of the grout material (gypsum cement) that will be used for stemming boreholes also was prepared for adsorption testing. The samples are abbreviated as follows: Tiva Canyon Tuff (TCT), Yucca Mountain Tuff (YMT), Pah Canyon Tuff (PCT), bedded tuff (BT), Topopah Spring Tuff (abbreviated as TST4 and TST5 to identify whether the sample is from borehole UZ4 or UZ5, respectively), clinoptilolite (CLINO), and gypsum cement (GC).

\section{Sample Preparation}

The sample cores were crushed, successively, with a sledgehammer, jawcrusher, and roller crusher. The sledgehammer was used to reduce the cores to about 5-mm-diameter fragments; the jawcrusher then reduced the fragments to particles of less than $1 \mathrm{~mm}$; and the roller crusher reduced the particles to a size of less than $500 \mu \mathrm{m}$. The samples were then sieved to provide samples with particle sizes of 63-150, $150-250$, and $250-500 \mu \mathrm{m}$. An additional identifier was added to the sample abbreviations to reflect the sample particle size; for example, the Yucca Mountain Tuff samples are abbreviated as YMT 63-150, YMT 150-250, and YMT 250-500.

\section{Sample Characterization}

The adsorptive capacities of rock and grout material are controlled by their physical and chemical properties. Identification of those properties that directly influence the sorptive capability of rock and grout material will allow for development of a model predicting the sorptive behavior of $\mathrm{SF}_{6}$ at Yucca Mountain. Three physical and chemical properties of the samples were measured: cation-exchange capacity, surface area, and mineralogy. In addition, the bulk density and porosity of each sample was determined so that the solid volume of the sample used in the tests could be calculated.

\section{Density and porosity}

The bulk densities of the crushed samples (table 2) were determined by first measuring the volume of each sample in a volumetric beaker and then weighing the sample. The porosities of the crushed samples were calculated from:

$$
\rho_{b}=\rho_{g}(1-\Theta)
$$

where,

$\rho_{b}=$ bulk density of sample, $\mathrm{g} / \mathrm{cm}^{3}$;

$\rho_{g}=$ grain density of sample, $\mathrm{g} / \mathrm{cm}^{3}$; and

$\Theta=$ porosity of sample, dimensionless.

The grain densities used for calculating the sample porosities are from samples similar to those used in the adsorption experiment (Dayal and Klein, 1988; Ming and Mumpton, 1989; Flint and Flint, 1990; Flint and others, 1993).

The porosities of the crushed tuffs ranged from 54 to 70 percent (includes both the inter- and intragrain porosities) with the nonwelded tuffs having higher porosities than the densely welded tuffs. The 


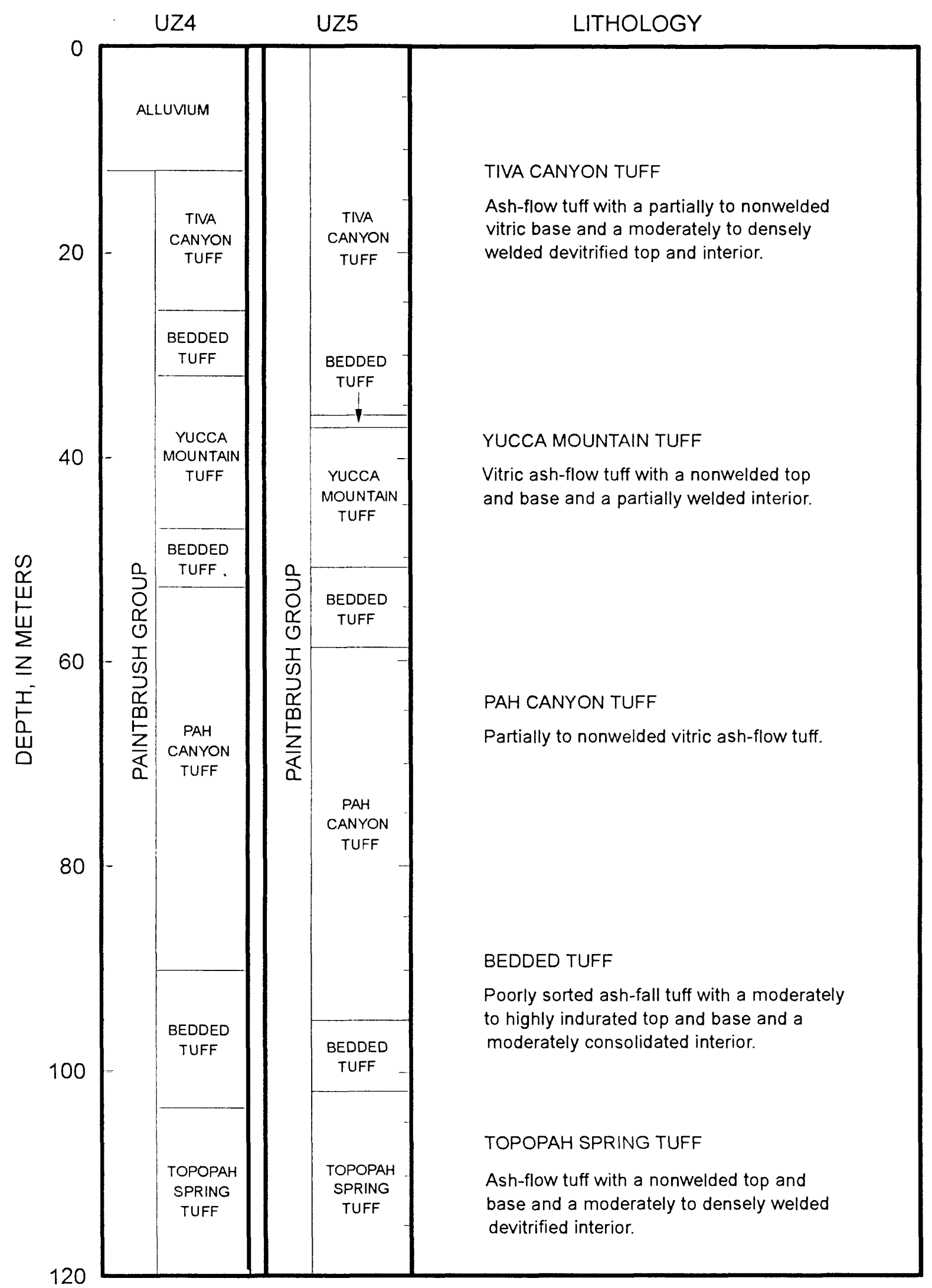

Figure 2. Diagram of the depth and extent of geologic units at boreholes UE-25 UZ \#4 and UE-25 UZ \#5. Lithologic descriptions are modified from Loskot and Hammermeister (1992). 
Tabie 1. Sample collection depth and degree of welding of tuff samples

\begin{tabular}{lcccc}
\hline Sample & $\begin{array}{c}\text { UZ4 depth } \\
\text { (meters) }\end{array}$ & $\begin{array}{c}\text { Degree } \\
\text { of } \\
\text { welding }\end{array}$ & $\begin{array}{c}\text { UZ5 depth } \\
\text { (meters) }\end{array}$ & $\begin{array}{c}\text { Degree of } \\
\text { welding }\end{array}$ \\
\hline Tiva Canyon Tuff & Collected on top of Yucca Mountain & $\begin{array}{l}\text { Moderate } \\
\text { to dense }\end{array}$ \\
Yucca Mountain Tuff & $34.2-35.1$ & Non & $37.9-38.0$ & Non \\
& $36.8-37.1$ & Partly & & \\
& $40.7-44.3$ & Non & & \\
Pah Canyon Tuff & $5.5-57.9$ & Non & $66.1-68.0$ & Non \\
& $61.0-61.1$ & Non & $75.3-82.0$ & Non \\
& $72.2-73.5$ & Non & $86.4-88.0$ & Non \\
& & & & \\
Bedded Tuff & $90.4-92.7$ & & $96.0-96.7$ & \\
& $99.1-103.0$ & & $98.3-101.4$ & \\
& $\cdot$ & & & \\
Topopah Spring Tuff & $106.1-106.3$ & Dense & $101.5-101.7$ & Non \\
& $109.7-110.0$ & Dense & $102.4-102.6$ & Non \\
& & & $104.7-104.8$ & Non \\
\hline
\end{tabular}

bulk densities of the crushed tuffs varied from 0.69 to $1.05 \mathrm{~g} / \mathrm{cm}^{3}$, with the densely welded Tiva Canyon Tuff and Topopah Spring Tuff, UZA, samples having the highest densities $\left(0.83\right.$ to $\left.1.05 \mathrm{~g} / \mathrm{cm}^{3}\right)$ and the nonwelded Topopah Spring Tuff, UZ5; Pah Canyon Tuff; and bedded tuff samples having the lowest densities $\left(0.69\right.$ to $\left.0.88 \mathrm{~g} / \mathrm{cm}^{3}\right)$.

\section{Cation-exchange capacity}

The cation-exchange capacities were measured by Crystal Research Laboratories (Golden, Colo.) by saturating the samples with a solution of ammonium carbonate at a pH of 7.0. The samples were then heated to $100^{\circ} \mathrm{C}$ and analyzed for nitrogen gas (Lewis-Russ, 1990; Maynard Slaughter, Crystal Research Laboratories, oral commun., 1994).

The range of cation-exchange capacities observed for the crushed samples (table 2) fall into three groups: (1) samples with cation exchangecapacities of less than $10 \mathrm{meq} / 100$ grams (Tiva Canyon Tuff, Pah Canyon Tuff); (2) samples with cationexchange capacities between $10-50 \mathrm{meq} / 100$ grams (Yucca Mountain Tuff; Topopah Spring Tuff, UZA; gypsum cement); and (3) samples with cationexchange capacities of greater than $100 \mathrm{meq} / 100$ grams
(Topopah Spring Tuff, UZ5; bedded tuff; clinoptilolite).

\section{Surface area}

Prior to (1.5 years) starting the $\mathrm{SF}_{6}$ adsorption tests, single-point surface-area determinations were made on all the crushed samples with a Quantasorb sorption analyzer (table 3 ). The single-point measurements were made at one partial pressure of adsorbate (nitrogen, $\mathrm{N}_{2}$ ) using a 30-70 percent $\mathrm{N}_{2}-\mathrm{He}$ (helium) mixture as the analysis gas. Samples were prepared for surface-area analyses by flowing 100 percent helium gas through the sample at outgassing temperatures of $70^{\circ}$ and $230^{\circ} \mathrm{C}$ for at least 3 hours. The reliability of the analytical instrument and procedure was tested by comparing the measured surface-area $\left(9.2 \mathrm{~m}^{2} / \mathrm{g}\right)$ of the KGa-1 kaolinite (KGa-1 kaolin, Washington County, Georgia) with published values $\left(10.1 \mathrm{~m}^{2} / \mathrm{g}\right.$, LewisRuss, 1990; $11.2 \mathrm{~m}^{2} / \mathrm{g}$, Carroll-Webb and Walther, 1988).

Immediately following the adsorption tests, multi-point surface-area determinations (measured at various partial pressures of adsorbate, $\mathrm{N}_{2}$ ) were made for samples used in the adsorption tests. The samples 
Table 2. Densities, porosities, and cation-exchange capacities for crushed tuffs, gypsum cement, and clinoptilolite

[Bulk density measurements were repeatable within \pm 5 percent. TCT, Tiva Canyon Tuff; YMT, Yucca Mountain Tuff; PCT, Pah Canyon Tuff; BT, bedded tuff; TST4, Topopah Spring Tuff, UZ4; TST5, Topopah Spring Tuff, UZ5; GC, gypsum cement; CLINO, clinoptilolite; 63-150, 150-250, and 250-500 are crushed rock sizes in micrometers; $\mathrm{g} / \mathrm{cm}^{3}$, gram per centimeter cubed; $\%$, percent; meq $100 \mathrm{~g}$, milliequivalents per 100 grams; \pm , plus or minus; --, no data]

\begin{tabular}{|c|c|c|c|c|}
\hline Sample & $\begin{array}{l}\text { Bulk density } \\
\rho_{b}\left(g / \mathrm{cm}^{3}\right)\end{array}$ & $\begin{array}{c}\text { Graln density } 1 \\
\rho_{g}\left(g / \mathrm{cm}^{3}\right)\end{array}$ & $\begin{array}{c}\text { Porosity } 2 \\
\theta(\%)\end{array}$ & $\begin{array}{l}\text { Cation-exchange } \\
\text { capaclty } \\
\text { (meq/100 g) }\end{array}$ \\
\hline TCT $150-250$ & 1.00 & 2.4 & 58 & $2.1 \pm 2.1$ \\
\hline YMT 63-150 & 0.90 & 2.3 & 61 & $17.84 \pm 6.9$ \\
\hline YMT 150-250 & 0.93 & 2.3 & 60 & $17.13 \pm 6.7$ \\
\hline YMT 250-500 & 0.85 & 2.3 & 63 & $9.28 \pm 4.3$ \\
\hline РCT 63-150 & 0.76 & 2.4 & 68 & $9.28 \pm 4.3$ \\
\hline PCT 150-250 & 0.77 & 2.4 & 68 & $5.71 \pm 2.8$ \\
\hline РCT 250-500 & 0.73 & 2.4 & 70 & $7.14 \pm 3.4$ \\
\hline BT 63-150 & 0.72 & 2.3 & 69 & $103.5 \pm 5.2$ \\
\hline BT $150-250$ & 0.69 & 2.3 & 70 & $102.8 \pm 5.1$ \\
\hline BT $250-500$ & 0.81 & 2.3 & 65 & $103.5 \pm 5.2$ \\
\hline TST4 63-150 & 0.89 & 2.3 & 61 & $52.83 \pm 5.1$ \\
\hline TST4 150-250 & 0.83 & 2.3 & 64 & $49.26 \pm 5.3$ \\
\hline TST4 250-500 & 1.05 & 2.3 & 54 & $38.55 \pm 7.8$ \\
\hline TST5 63-150 & 0.77 & 2.3 & 67 & $119.2 \pm 6.0$ \\
\hline TST5 150-250 & 0.83 & 2.3 & 64 & $116.4 \pm 5.8$ \\
\hline TST5 250-500 & 0.88 & 2.3 & 62 & $129.9 \pm 6.5$ \\
\hline GC 63-150 & 0.82 & 2.2 & 63 & -- \\
\hline GC $150-250$ & 0.89 & 2.2 & 60 & $14.99 \pm 6.2$ \\
\hline GC $250-500$ & -- & 2.2 & - & $11.42 \pm 5.1$ \\
\hline CLINO $150-250$ & 0.87 & 2.2 & 62 & $127.5 \pm 10$ \\
\hline
\end{tabular}


Table 3. Surface-area analyses ${ }^{1}\left(\mathrm{~m}^{2} / \mathrm{g}\right)$ of crushed tuffs, gypsum cement, clinoptilolite, and kaolinite

$[-$, no data $]$

\begin{tabular}{|c|c|c|c|c|}
\hline \multirow{3}{*}{ Sampies } & \multicolumn{4}{|c|}{ Outgassing temperature, degrees Ceisius ( $\left.{ }^{\circ} \mathbf{C}\right)$} \\
\hline & \multicolumn{2}{|c|}{ Singie-point } & \multicolumn{2}{|c|}{ Multi-point } \\
\hline & $70^{\circ} \mathrm{C}$ & $230^{\circ} \mathrm{C}$ & $150^{\circ} \mathrm{C}$ & $230^{\circ} \mathrm{C}$ \\
\hline TCT $150-250^{2,3}$ & 0.79 & 0.97 & 0.81 & 0.93 \\
\hline YMT 63-150 & 12.2 & $13.4 \pm 1.52$ & -- & -- \\
\hline YMT 150-250 & 14.1 & $15.8 \pm 0.15$ & 9.16 & 10.1 \\
\hline YMT 250-500 & 17.2 & $15.2 \pm 0.10$ & -- & -- \\
\hline PCT 63-150 & 4.28 & $5.61 \pm 0.16$ & -- & -- \\
\hline PCT 150-250 & 4.72 & $6.10 \pm 0.13$ & 5.29 & 5.61 \\
\hline PCT 250-500 & 5.28 & $6.90 \pm 0.01$ & -- & -- \\
\hline BT 63-150 & $28.8 \pm 0.30$ & $32.9 \pm 0.65$ & -- & -- \\
\hline BT $150-250$ & $32.6 \pm 0.90$ & $44.2 \pm 3.11$ & 23.8 & 22.9 \\
\hline BT $250-500$ & $26.9 \pm 0.25$ & $41.1 \pm 0.55$ & -- & -- \\
\hline TST4 63-150 & 10.1 & $12.3 \pm 2.07$ & -- & -- \\
\hline TST4 150-250 & 10.5 & $13.8 \pm 0.45$ & 8.41 & 8.42 \\
\hline TST4 250-500 & 9.06 & $9.03 \pm 0.50$ & -- & -- \\
\hline TST5 63-150 & 21.8 & $37.6 \pm 0.75$ & -- & -- \\
\hline TST5 150-250 & 30.8 & $40.2 \pm 0.30$ & 24.3 & 23.8 \\
\hline TST5 250-500 & 29.0 & $41.2 \pm 0.40$ & -- & -- \\
\hline GC 63-150 & -- & -- & 5.13 & 5.37 \\
\hline GC $150-250$ & 18.5 & $16.8 \pm 2.67$ & -- & -- \\
\hline GC $250-500$ & 15.1 & $11.5 \pm 3.22$ & - & -- \\
\hline CLINO $150-250^{3}$ & -- & - & 12.2 & 12.1 \\
\hline KGa-1 kaolin ${ }^{3}$ & 8.49 & 9.20 & -- & -- \\
\hline Kaolinite $^{4}$ & -- & -- & 16.0 & -- \\
\hline
\end{tabular}

${ }^{1}$ Single-point surface-area analyses were determined with a Quantasorb sorption analyzer manufactured by Quantachrome Corp., New York. Multi-point surface-area analyses were determined with a Micromeritics Gemini 2360 surface-area analyzer. Both instruments are maintained by the U.S. Geological Survey Water Quality Laboratory, Arvada, Colo.

${ }^{2}$ Refer to table 2 for explanation of sample labels and symbols.

${ }^{3}$ Single-point surface-area values $\left(230^{\circ} \mathrm{C}\right)$ in Lewis-Russ (1990): TCT $=0.9 \pm 0.17$;

Clinoptilolite $=17 \pm 0.9 ; \mathrm{KGa}-1 \mathrm{Kaolin}=10.1$.

${ }^{4}$ Reference value of $16.10 \pm 0.8 \mathrm{~m}^{2} / \mathrm{g}$ from Micromeritics, Norcross, Georgia. 
were outgassed in a helium environment at temperatures of $150^{\circ}$ and $230^{\circ} \mathrm{C}$ and analyzed with a Gemini 2360 surface-area analyzer using 100 percent $\mathrm{N}_{2}$ as the analysis gas. The accuracy of the instrument was determined by comparing the measured $\left(16.0 \mathrm{~m}^{2} / \mathrm{g}\right)$ and reference $\left(16.10 \pm 0.8 \mathrm{~m}^{2} / \mathrm{g}\right)$ value of a kaolinite reference material supplied with the instrument (Micromeritics, Norcross, Georgia).

The single-point surface-areas obtained when the outgassing temperature was $230^{\circ} \mathrm{C}$ were significantly higher than surface-areas obtained when the outgassing temperature was $70^{\circ} \mathrm{C}$. This discrepancy is probably due to more efficient removal of contaminants from samples at higher temperatures (Ming and Mumpton, 1989). The lower single-point values do, however, compare favorably with the multi-point measurements of each sample. Because the multi-point surface-area measurements were determined immediately following the adsorption tests, these measurements are a better representation of the samples during the tests. Consequently, the multi-point measurements were used in our retention calculations (see below). On the basis of the multi-point measurements, the tuffs can be separated into three distinct groups: (1) samples with surface areas less than $1 \mathrm{~m}^{2} / \mathrm{g}$ (Tiva Canyon Tuff); (2) samples with surface areas between 5 and $10 \mathrm{~m}^{2} / \mathrm{g}$ (Pah Canyon Tuff; Yucca Mountain Tuff; Topopah Spring Tuff, UZ4); and (3) samples with surface areas greater than $20 \mathrm{~m}^{2} / \mathrm{g}$ (Topopah Spring Tuff, UZ5; bedded tuff).

\section{Mineralogy}

The mineralogies of the crushed tuff, grout, and clinoptilolite samples (table 4) were determined by $\mathrm{X}$-ray diffraction. The relative abundances of the minerals were estimated from the diffractometer patterns by comparing the patterns with peak intensities of internal standards (Klug and Alexander, 1974; Sheppard and Gude, 1982). This work was performed by Crystal Research Laboratories (Golden, Colo.) and the USGS Branch of Geochemistry (Lakewood, Colo.).

From the mineralogical analyses, most of the tuff samples can be categorized as containing either a primary or secondary assemblage of minerals. The unaltered tuffs contain a large percentage of unstable, primary phases such as glass, tridymite, and cristobalite (Vaniman and others, 1984). These constituents are major phases in the Tiva Canyon Tuff, Yucca Mountain Tuff, and Pah Canyon Tuff. Conversely, the bedded tuff and Topopah Spring Tuff, UZ5, samples are composed of approximately 50 percent secondary zeolites. The principal zeolite minerals in these sam- ples are clinoptilolite and/or heulandite (Steve Sutley, USGS Branch of Geochemistry, written commun., 1994; Maynard Slaughter, Crystal Research Laboratories, written commun., 1994). The densely welded Topopah Spring Tuff, UZA, sample has an intermediate mineral assemblage as shown by its moderate amount of both cristobalite and zeolite. The high percentage of zeolites in the Topopah Spring Tuff samples (TST4, 19 percent; TST5, 50 percent) are not representative of the entire Topopah Spring Tuff, and are typically found only near the base of the unit (Vaniman and others, 1984).

The percent of zeolite in a sample appears to have a large influence on the cation-exchange capacity and surface area of the sample. Samples with high percentages of zeolite have the highest cation-exchange capacities and surface areas (Topopah Spring Tuff, UZ4 and 5; bedded tuff), while samples with little or no zeolite have small cation-exchange capacities and surface areas (Tiva Canyon Tuff, Pah Canyon Tuff). This is not true of the Yucca Mountain Tuff, however, which does not contain any zeolite but does have a moderate cation-exchange capacity and surface area.

\section{Adsorption Test Method}

The adsorption test method includes the design of the adsorption test apparatus, sample conditioning, and the experiment components.

\section{Test Apparatus}

The adsorption-test apparatus (fig. 3) consists of five integrated parts: (1) cylinders containing the test gas mixture; (2) the sample flasks; (3) a vacuum pump; (4) a pressure gage; and (5) a glass manifold. The apparatus parts were connected to the glass manifold, with the test-gas cylinder, sample flasks, and vacuum pump capable of being isolated using stopcocks.

The sample flasks (fig. 4) were connected to the glass manifold by a glass extension tube. Sample was added to the flask by removing the Teflon bushing and pouring the crushed material into the flask. The Teflon bushing was then reattached to the flask and formed a leakproof seal. Gas samples were collected with a syringe through a septum connected to the glass sleeve.

\section{Sample Conditioning}

Knowlton and others (1981) identified three types of water associated with the zeolite clinoptilolite: external water, loosely bound zeolitic water, and tightly bound zeolitic water, which are removed from clinop- 


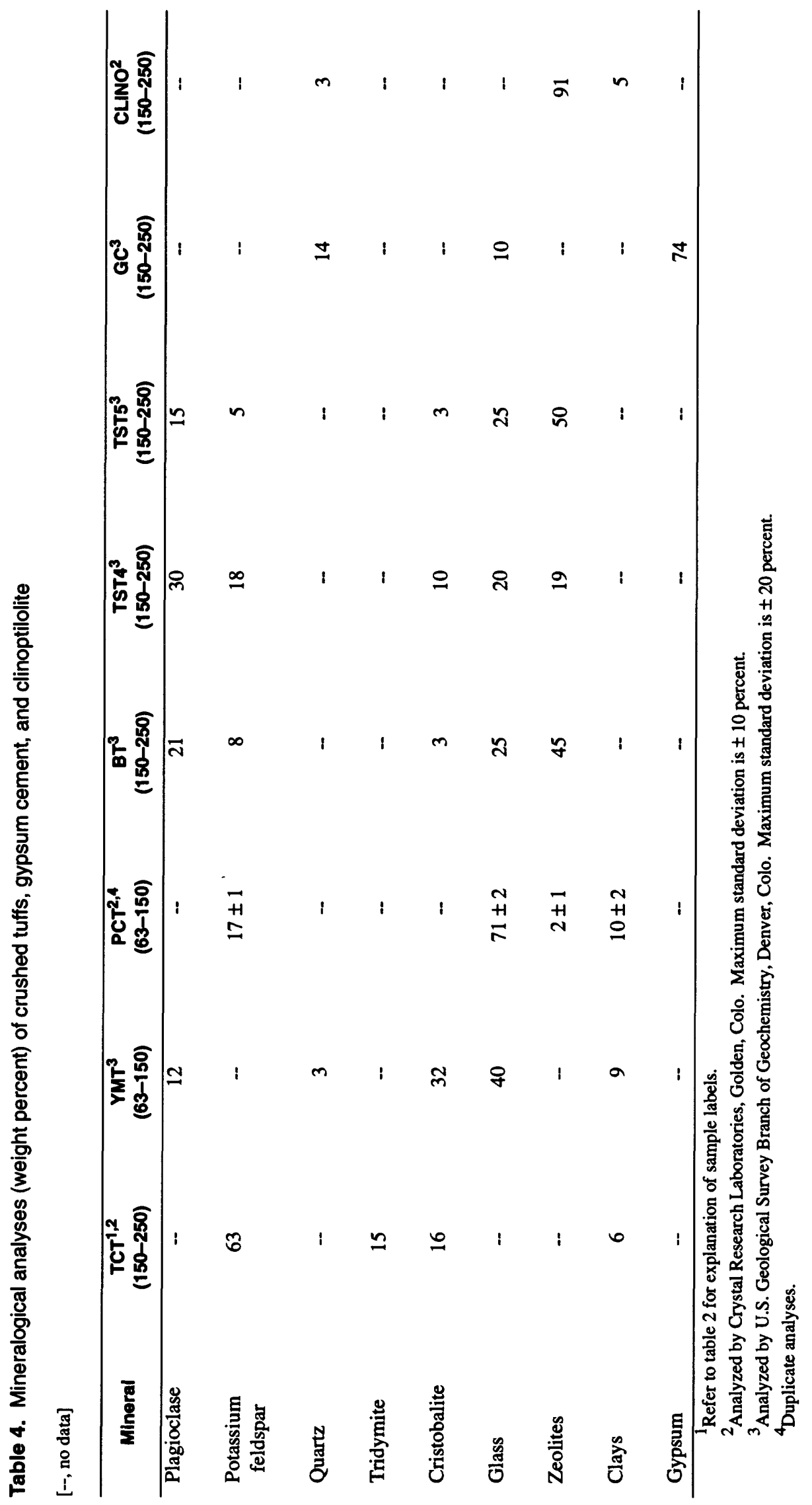




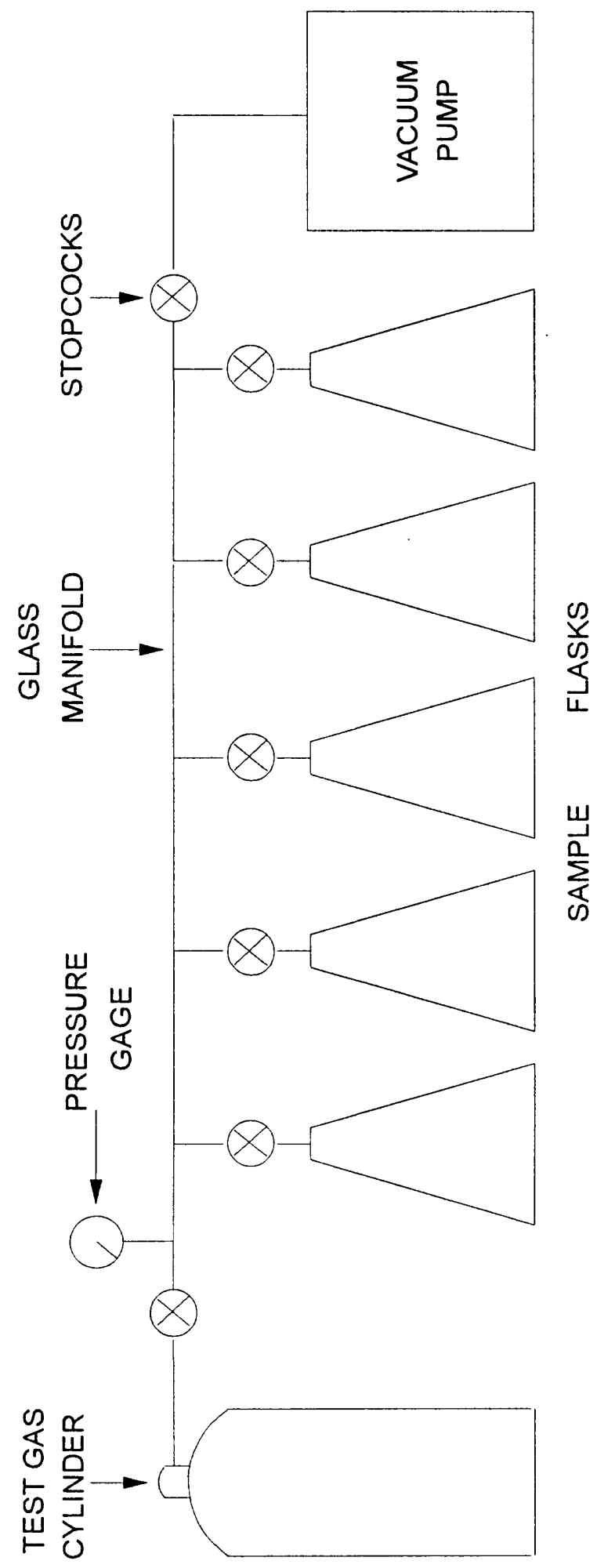

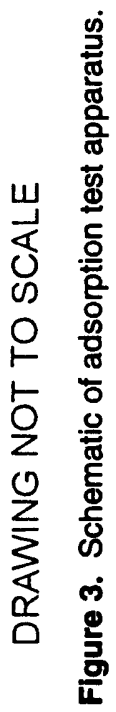




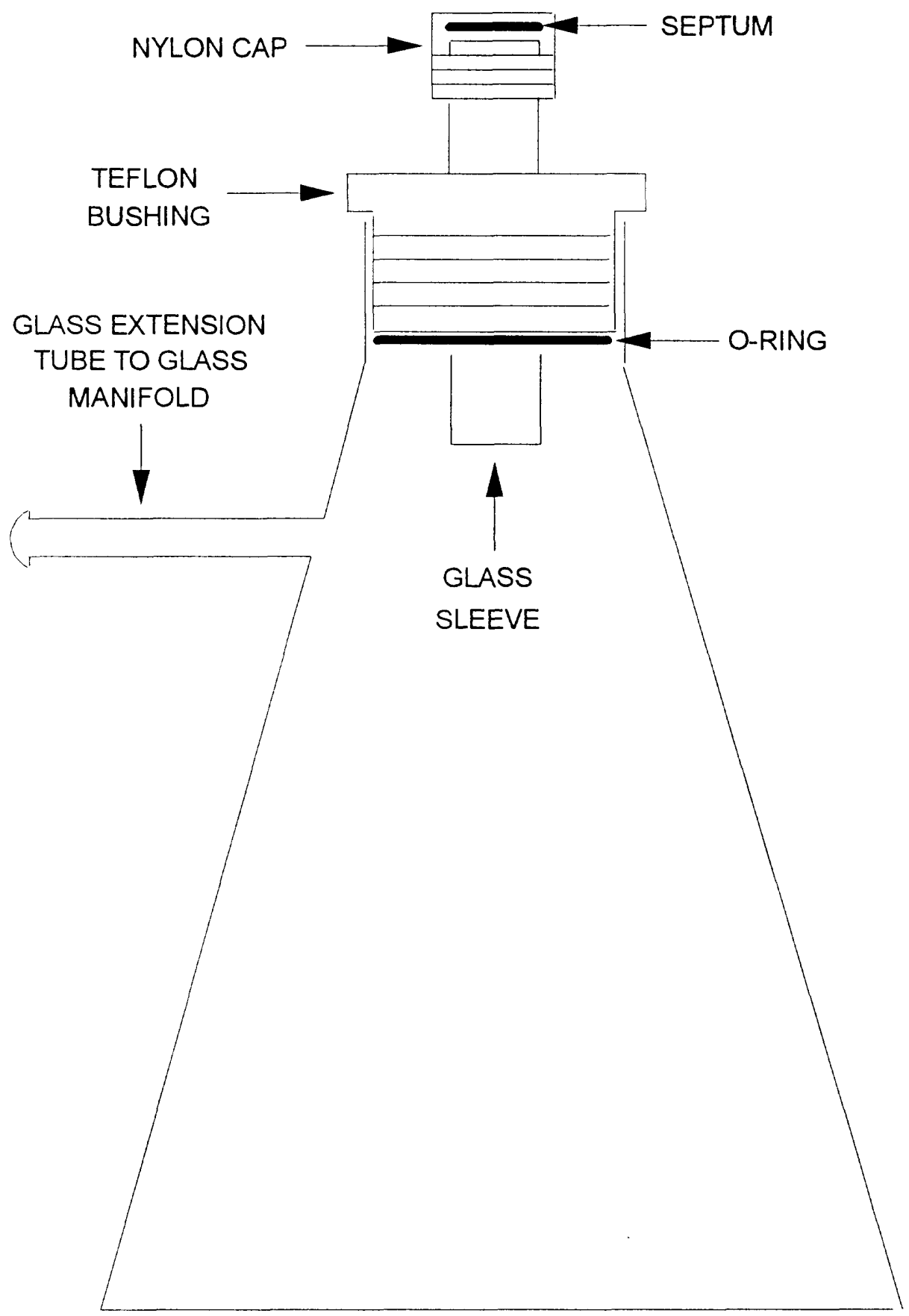

DRAWING NOT TO SCALE

Figure 4. Detailed diagram of sample flask. 
tilolite at $75^{\circ}, 171^{\circ}$, and $271^{\circ} \mathrm{C}$, respectively. Although temperatures in excess of $300^{\circ} \mathrm{C}$ have been used by some researchers to dehydrate zeolitic tuffs (Sheppard and Gude, 1982; Ming and Mumpton, 1989), long-term heating at temperatures as low as $200^{\circ} \mathrm{C}$ will alter some clinoptilolites (Bish, 1990). To minimize alteration of the samples, they were dehydrated for 1 week at $150^{\circ} \mathrm{C}$. The samples were then evacuated overnight at $0.13 \mathrm{~Pa}$.

Since the crushed samples were reused in successive adsorption tests, the $\mathrm{SF}_{6}$ adsorbed onto the samples from the previous test had to be removed. A series of desorption tests showed that baking the samples at a temperature of $150^{\circ} \mathrm{C}$ rapidly removed $\mathrm{SF}_{6}$ from the samples. To ensure that $\mathrm{SF}_{6}$ was completely removed, the samples were baked in an oven at $150^{\circ} \mathrm{C}$ for 2 hours. The samples were then evacuated for 2 hours at $0.13 \mathrm{~Pa}$.

\section{Experiment Components}

The adsorption experiment has several variable components, including: (1) the moisture content of the samples, (2) the equilibration time of the tests, (3) the particle size of the samples, (4) the amount of $\mathrm{SF}_{6}$ injected into the flasks, and (5) the amount of sample tested. To determine adsorption isotherms, the amount of $\mathrm{SF}_{6}$ injected into the flasks must vary while the other components remain constant (Serne, 1992).

\section{Fixed components}

The in-situ moisture content of the sample cores varied from 1 to 25 weight-percent. Because water competes with $\mathrm{SF}_{6}$ for available adsorption sites (Houston and others, 1989), all of the crushed samples were dried before being used in the tests. In tests with an initial flask atmosphere concentration of 1.94 parts per million by volume (ppmv) $\mathrm{SF}_{6}$, the amount of $\mathrm{SF}_{6}$ adsorbed onto dry samples of bedded tuff (about 65 to 80 picomoles per gram) decreased 15 to 35 percent (to $50-55 \mathrm{pmol} / \mathrm{g}$ ) when the tuff was wetted with 10 weight-percent of deionized water (fig. 5).

The time required for $\mathrm{SF}_{6}$ to equilibrate between the flask atmosphere and test sample was determined by reaching a steady-state concentration of $\mathrm{SF}_{6}$ in the flask atmosphere. Initial tests indicated that the time required for the flask atmosphere, with a starting $\mathrm{SF}_{6}$ concentration of $1.94 \mathrm{ppmv}$, to reach steady state was less than 25 hours when in contact with samples of dry bedded tuff and the Pah Canyon Tuff. With identical starting conditions, the flask atmosphere took less than 50 hours to reach steady state with samples of wet bedded tuff and the Yucca Mountain Tuff (figs. 5 and 6). A similar study by Houston and others (1989) determined equilibration times of less than 17 hours for several halogenated gaseous compounds with soils. Consequently, the adsorption tests were run for a minimum of 41 hours and a maximum of 379 hours, with most test lengths ranging between 41 and 90 hours (table 5).

The adsorption of $\mathrm{SF}_{6}$ onto dry bedded tuff varied slightly ( 70 to $80 \mathrm{pmol} / \mathrm{g}$ ) with particle size for particle sizes between 63 and $500 \mu \mathrm{m}$ (fig. 5). For samples of Pah Canyon Tuff, Yucca Mountain Tuff, and wet bedded tuff, particle size had no effect on the adsorption of $\mathrm{SF}_{6}$ within measurement error (fig. 6). Particle size also had no measurable effect on the cationexchange capacities or the surface-area measurements of the tuffs (tables 2 and 3 ). These results concur with studies undertaken at Los Alamos National Laboratory that investigated the sorption of radionuclides onto saturated Yucca Mountain tuffs (Thomas, 1987). Their results show that particle sizes of 75 to $500 \mu \mathrm{m}$ have similar sorptive capacities, but that particle sizes of less than $38 \mu \mathrm{m}$ could lead to larger sorption ratios. From the above information it was evident that the particle size of the crushed tuff samples would have no influence on the adsorption experiments; however, for consistency, only samples with a particle size of 150 to $250 \mu \mathrm{m}$ were used in the adsorption tests (except for gypsum cement, which had a particle size of 63-150 $\mu \mathrm{m})$.

\section{Variable components}

The amount of $\mathrm{SF}_{6}$ injected into the flasks was calculated from the ideal gas law:

$$
n_{\mathrm{SF} 6}=P_{\mathrm{SF} 6} V+R T
$$

where,

$$
\begin{aligned}
& n_{\mathrm{SF} 6}=\text { number of moles of } \mathrm{SF}_{6}, \mathrm{~mol} ; \\
& P_{\mathrm{SF} 6}=\text { partial pressure of } \mathrm{SF}_{6}, \mathrm{~Pa} ; \\
& V=\text { volume of gas injected, } \mathrm{m}^{3} ; \\
& R=\text { gas constant, } 8.314 \mathrm{~Pa} \cdot \mathrm{m}^{3} \cdot \mathrm{K}^{-1} \cdot \mathrm{mol}^{-1} ; \text { and } \\
& T=\text { temperature, constant at } 293 \text { degrees Kelvin. }
\end{aligned}
$$

The partial pressure of $\mathrm{SF}_{6}$ is the product of the concentration of $\mathrm{SF}_{6}$ and gas pressure in the experiment flask. The concentrations of $\mathrm{SF}_{6}$ that were injected into the flasks were $0.103,1.00$, and $1.94 \mathrm{ppmv}$ in a background of nitrogen. These concentrations span the concentration range of $\mathrm{SF}_{6}$ that may be present in the unsaturated zone from drilling operations at Yucca Mountain. The volume of gas injected into the flasks was calculated from the following equations: 


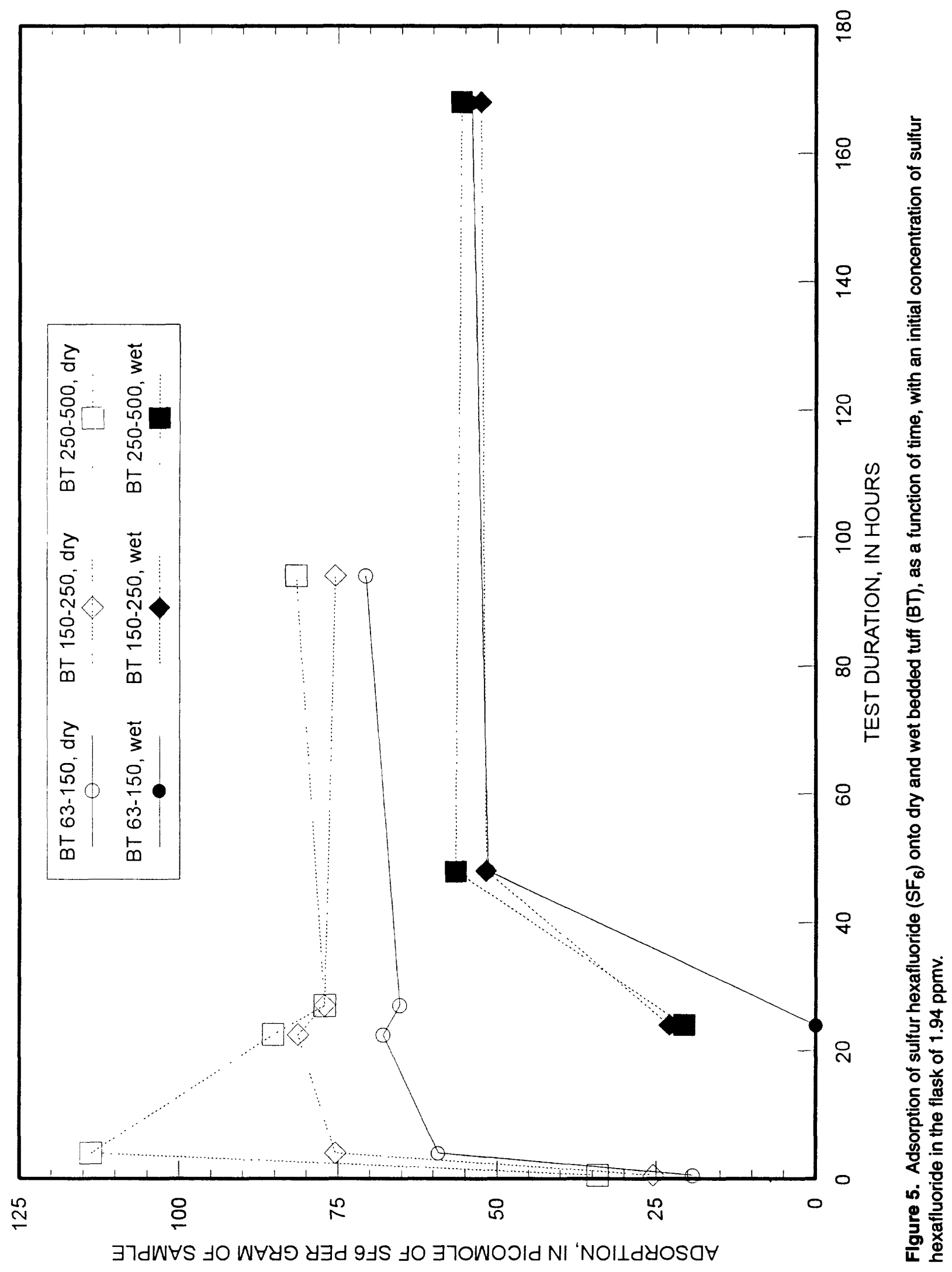




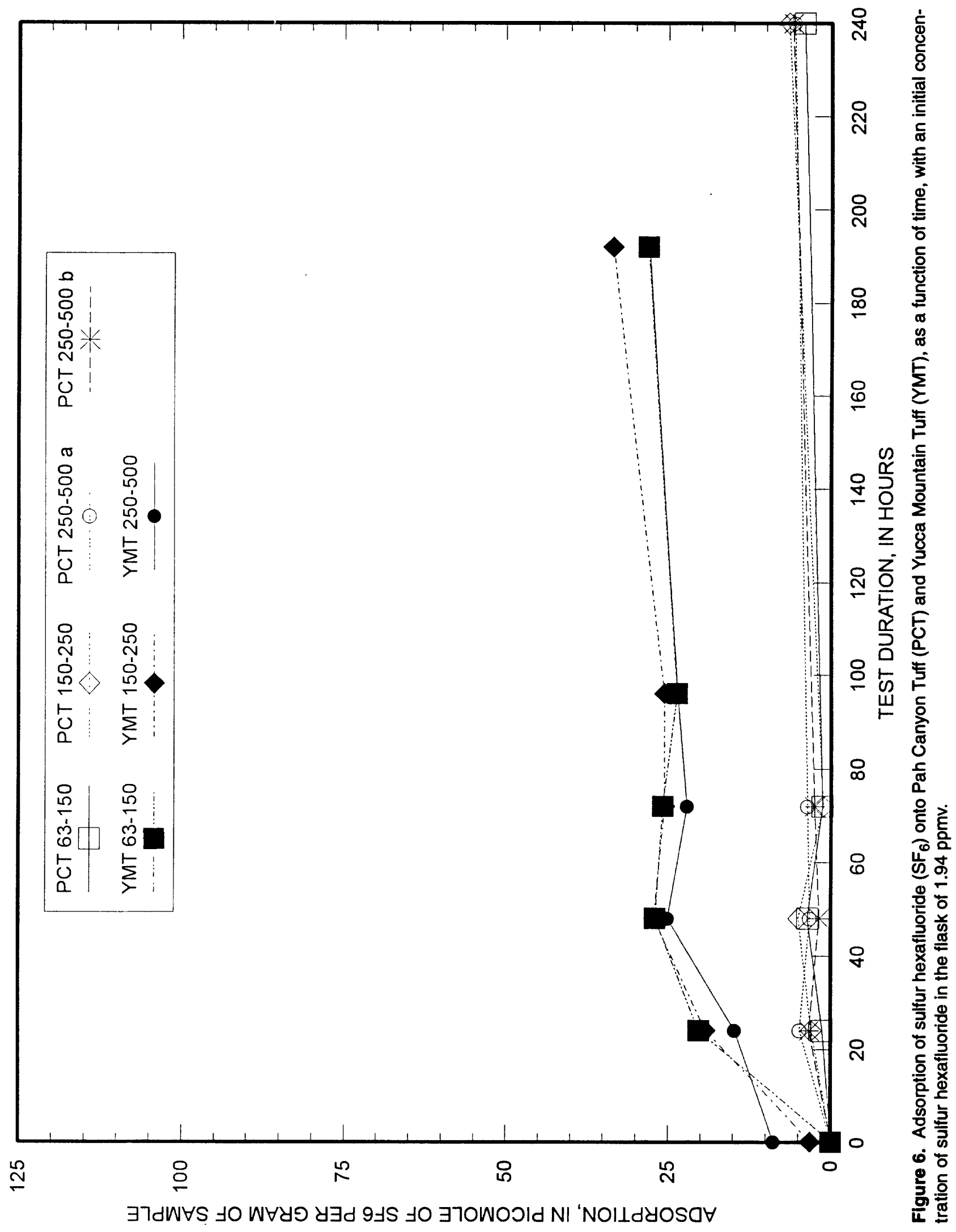


Table 5. Adsorption test data

[ $\mu \mathrm{m}$, micrometers; $\mathrm{Pa}$, pascal; pmol/g, picomoles per gram]

\begin{tabular}{|c|c|c|c|c|c|}
\hline \multirow{2}{*}{$\begin{array}{c}\text { Test } \\
\text { number }\end{array}$} & \multicolumn{2}{|c|}{ Mole fraction $\mathrm{SF}_{6}$} & \multirow{2}{*}{$\begin{array}{l}\text { Test length } \\
\text { (hours) }\end{array}$} & \multirow{2}{*}{$\begin{array}{l}\text { Total pressure } \\
(\mathrm{Pa})\end{array}$} & \multirow{2}{*}{$\begin{array}{l}\text { Sorption } \\
\text { (pmolg) }\end{array}$} \\
\hline & Initial & Final & & & \\
\hline \multicolumn{6}{|c|}{$\begin{array}{c}\text { Tiva Canyon Tuff } \\
150-250 \mu \mathrm{m}, 198 \text { grams }\end{array}$} \\
\hline TCT-1 & $1.03 \times 10^{-7}$ & $1.004 \times 10^{-7}$ & 41 & 99,057 & 0.313 \\
\hline TCT-2 & $1.03 \times 10^{-7}$ & $1.005 \times 10^{-7}$ & 42 & 99,457 & 0.302 \\
\hline TCT-3 & $1.03 \times 10^{-7}$ & $1.026 \times 10^{-7}$ & 67 & 98,257 & 0.048 \\
\hline TCT-4 & $1.03 \times 10^{-7}$ & $1.027 \times 10^{-7}$ & 378 & 99,323 & 0.036 \\
\hline TCT-5 & $1.00 \times 10^{-6}$ & $8.92 \times 10^{-7}$ & 66 & 98,523 & 12.9 \\
\hline TCT-6 & $1.00 \times 10^{-6}$ & $9.41 \times 10^{-7}$ & 88 & 98,523 & 7.07 \\
\hline TCT-7 & $1.00 \times 10^{-6}$ & $9.87 \times 10^{-7}$ & 112 & 100,390 & 1.59 \\
\hline TCT-8 & $1.00 \times 10^{-6}$ & $9.42 \times 10^{-7}$ & 43 & 98,390 & 6.94 \\
\hline TCT-9 & $1.94 \times 10^{-6}$ & $1.82 \times 10^{-6}$ & 66 & 98,124 & 14.0 \\
\hline TCT-10 & $1.94 \times 10^{-6}$ & $1.86 \times 10^{-6}$ & 90 & 100,923 & 10.7 \\
\hline TCT-11 & $1.94 \times 10^{-6}$ & $1.79 \times 10^{-6}$ & 90 & 97,590 & 18.4 \\
\hline \multicolumn{6}{|c|}{$\begin{array}{l}\text { Yucca Mountain Tuff } \\
150-250 \mu \mathrm{m}, 119 \text { grams }\end{array}$} \\
\hline YMT-1 & $1.03 \times 10^{-7}$ & $8.59 \times 10^{-8}$ & 41 & 99,590 & 3.69 \\
\hline YMT-2 & $1.03 \times 10^{-7}$ & $9.34 \times 10^{-8}$ & 42 & 99,190 & 2.06 \\
\hline YMT-3 & $1.03 \times 10^{-7}$ & $8.97 \times 10^{-8}$ & 67 & 99,323 & 2.86 \\
\hline YMT-4 & $1.03 \times 10^{-7}$ & $8.76 \times 10^{-8}$ & 378 & 99,590 & 3.33 \\
\hline YMT-5 & $1.00 \times 10^{-6}$ & $8.53 \times 10^{-7}$ & 66 & 99,057 & 31.6 \\
\hline YMT-6 & $1.00 \times 10^{-6}$ & $8.30 \times 10^{-7}$ & 88 & 98,523 & 36.3 \\
\hline YMT-7 & $1.00 \times 10^{-6}$ & $9.48 \times 10^{-7}$ & 112 & 99,990 & 11.3 \\
\hline YMT-8 & $1.00 \times 10^{-6}$ & $8.92 \times 10^{-7}$ & 43 & 98,523 & 23.1 \\
\hline YMT-9 & $1.94 \times 10^{-6}$ & $1.68 \times 10^{-6}$ & 66 & 97,587 & 54.3 \\
\hline YMT-10 & $1.94 \times 10^{-6}$ & $1.68 \times 10^{-6}$ & 90 & 100,790 & 56.6 \\
\hline YMT-11 & $1.94 \times 10^{-6}$ & $1.63 \times 10^{-6}$ & 90 & 96,790 & 65.9 \\
\hline \multicolumn{6}{|c|}{$\begin{array}{l}\text { Pah Canyon Tuff } \\
150-250 \mu \mathrm{m}, 200 \text { grams }\end{array}$} \\
\hline PCT-1 & $1.03 \times 10^{-7}$ & $9.24 \times 10^{-8}$ & 41 & 97,857 & 1.28 \\
\hline PCT-2 & $1.03 \times 10^{-7}$ & $9.68 \times 10^{-8}$ & 42 & 97,990 & 0.75 \\
\hline PCT-3 & $1.03 \times 10^{-7}$ & $9.71 \times 10^{-8}$ & 67 & 97,057 & 0.71 \\
\hline PCT-4 & $1.03 \times 10^{-7}$ & $9.48 \times 10^{-8}$ & 378 & 99,057 & 1.01 \\
\hline PCT-5 & $1.00 \times 10^{-6}$ & $9.64 \times 10^{-7}$ & 43 & 97,324 & 4.32 \\
\hline PCT-6 & $1.00 \times 10^{-6}$ & $8.36 \times 10^{-7}$ & 66 & 98,390 & 19.9 \\
\hline PCT-7 & $1.00 \times 10^{-6}$ & $8.69 \times 10^{-7}$ & 88 & 97,724 & 15.8 \\
\hline PCT-8 & $1.00 \times 10^{-6}$ & $9.68 \times 10^{-7}$ & 112 & 99,723 & 3.94 \\
\hline PCT-9 & $1.94 \times 10^{-6}$ & $1.76 \times 10^{-6}$ & 66 & 97,724 & 21.5 \\
\hline PCT-10 & $1.94 \times 10^{-6}$ & $1.79 \times 10^{-6}$ & 90 & 100,923 & 19.1 \\
\hline PCT-11 & $1.94 \times 10^{-6}$ & $1.74 \times 10^{-6}$ & 90 & 97,324 & 24.5 \\
\hline
\end{tabular}


Table 5. Adsorption test data--Continued

\begin{tabular}{|c|c|c|c|c|c|}
\hline \multirow{2}{*}{$\begin{array}{c}\text { Test } \\
\text { number }\end{array}$} & \multicolumn{2}{|c|}{ Mole fraction $\mathrm{SF}_{6}$} & \multirow{2}{*}{$\begin{array}{l}\text { Test length } \\
\text { (hours) }\end{array}$} & \multirow{2}{*}{$\begin{array}{l}\text { Total pressure } \\
\text { (Pa) }\end{array}$} & \multirow{2}{*}{$\begin{array}{l}\text { Sorption } \\
\text { (pmol/g) }\end{array}$} \\
\hline & Initial & Final & & & \\
\hline \multicolumn{6}{|c|}{$\begin{array}{c}\text { Bedded Tuff } \\
150-250 \mu \mathrm{m}, 100 \text { grams }\end{array}$} \\
\hline BT-1 & $1.03 \times 10^{-7}$ & $7.09 \times 10^{-8}$ & 41 & 89,191 & 7.71 \\
\hline BT-2 & $1.03 \times 10^{-7}$ & $7.37 \times 10^{-8}$ & 42 & 89,724 & 7.08 \\
\hline BT-3 & $1.03 \times 10^{-7}$ & $6.87 \times 10^{-8}$ & 67 & 92,524 & 8.54 \\
\hline BT-4 & $1.03 \times 10^{-7}$ & $6.36 \times 10^{-8}$ & 379 & 90,924 & 9.65 \\
\hline BT-5 & $1.00 \times 10^{-6}$ & $6.81 \times 10^{-7}$ & 42 & 88,391 & 75.9 \\
\hline BT-6 & $1.00 \times 10^{-6}$ & $6.84 \times 10^{-7}$ & 66 & 90,924 & 77.4 \\
\hline BT-7 & $1.00 \times 10^{-6}$ & $7.13 \times 10^{-7}$ & 88 & 91,191 & 70.5 \\
\hline BT-8 & $1.00 \times 10^{-6}$ & $7.09 \times 10^{-7}$ & 112 & 90,924 & 71.2 \\
\hline BT-9 & $1.94 \times 10^{-6}$ & $1.38 \times 10^{-6}$ & 65 & 89,324 & 134 \\
\hline BT-10 & $1.94 \times 10^{-6}$ & $1.32 \times 10^{-6}$ & 90 & 88,258 & 148 \\
\hline BT-11 & $1.94 \times 10^{-6}$ & $1.41 \times 10^{-6}$ & 91 & 94,791 & 136 \\
\hline \multicolumn{6}{|c|}{$\begin{array}{l}\text { Bedded Tuff } \\
150-250 \mu \mathrm{m}, 200 \text { grams }\end{array}$} \\
\hline BT-1 & $1.03 \times 10^{-7}$ & $5.72 \times 10^{-8}$ & 41 & 78,792 & 4.54 \\
\hline BT-2 & $1.03 \times 10^{-7}$ & $4.79 \times 10^{-8}$ & 42 & 79,725 & 5.52 \\
\hline BT-3 & $1.03 \times 10^{-7}$ & $5.07 \times 10^{-8}$ & 67 & 86,658 & 5.70 \\
\hline BT-4 & $1.03 \times 10^{-7}$ & $4.54 \times 10^{-8}$ & 379 & 82,392 & 5.96 \\
\hline BT-5 & $1.00 \times 10^{-6}$ & $5.27 \times 10^{-7}$ & 42 & 79,059 & 47.0 \\
\hline BT-6 & $1.00 \times 10^{-6}$ & $5.26 \times 10^{-7}$ & 66 & 80,792 & 48.1 \\
\hline BT-7 & $1.00 \times 10^{-6}$ & $5.51 \times 10^{-7}$ & 88 & 80,659 & 45.5 \\
\hline BT-8 & $1.00 \times 10^{-6}$ & $5.44 \times 10^{-7}$ & 112 & 80,792 & 46.3 \\
\hline BT-9 & $1.94 \times 10^{-6}$ & $1.13 \times 10^{-6}$ & 65 & 79,592 & 81.3 \\
\hline BT-10 & $1.94 \times 10^{-6}$ & $1.07 \times 10^{-6}$ & 90 & 78,392 & 86.2 \\
\hline BT-11 & $1.94 \times 10^{-6}$ & $1.08 \times 10^{-6}$ & 91 & 83,458 & 89.8 \\
\hline \multicolumn{6}{|c|}{$\begin{array}{l}\text { Topopah Spring Tuff, UZA } \\
150-250 \mu \mathrm{m}, 100 \text { grams }\end{array}$} \\
\hline TST4-1 & $1.03 \times 10^{-7}$ & $8.66 \times 10^{-8}$ & 41 & 91,458 & 3.98 \\
\hline TST4-2 & $1.03 \times 10^{-7}$ & $8.63 \times 10^{-8}$ & 42 & 91,591 & 4.06 \\
\hline TST4-3 & $1.03 \times 10^{-7}$ & $8.27 \times 10^{-8}$ & 67 & 92,791 & 5.00 \\
\hline TST4-4 & $1.03 \times 10^{-7}$ & $8.05 \times 10^{-8}$ & 378 & 92,657 & 5.53 \\
\hline TST4-5 & $1.00 \times 10^{-6}$ & $8.17 \times 10^{-7}$ & 43 & 88,791 & 43.1 \\
\hline TST4-6 & $1.00 \times 10^{-6}$ & $7.58 \times 10^{-7}$ & 66 & 93,324 & 59.9 \\
\hline TST4-7 & $1.00 \times 10^{-6}$ & $7.96 \times 10^{-7}$ & 88 & 92,657 & 50.1 \\
\hline TST4-8 & $1.00 \times 10^{-6}$ & $8.07 \times 10^{-7}$ & 112 & 92,924 & 47.6 \\
\hline TST4-9 & $1.94 \times 10^{-6}$ & $1.59 \times 10^{-6}$ & 66 & 94,657 & 87.9 \\
\hline TST4-10 & $1.94 \times 10^{-6}$ & $1.64 \times 10^{-6}$ & 90 & 95,590 & 76.6 \\
\hline TST4-11 & $1.94 \times 10^{-6}$ & $1.64 \times 10^{-6}$ & 90 & 90,391 & 73.1 \\
\hline \multicolumn{6}{|c|}{$\begin{array}{l}\text { Topopah Spring Tuff, UZA } \\
150-250 \mu \mathrm{m}, 201 \text { grams }\end{array}$} \\
\hline TST4-1 & $1.03 \times 10^{-7}$ & $7.69 \times 10^{-8}$ & 41 & 81,192 & 2.52 \\
\hline TST4-2 & $1.03 \times 10^{-7}$ & $7.35 \times 10^{-8}$ & 42 & 81,725 & 2.87 \\
\hline TST4-3 & $1.03 \times 10^{-7}$ & $6.76 \times 10^{-8}$ & 67 & 85,191 & 3.59 \\
\hline TST4-4 & $1.03 \times 10^{-7}$ & $6.39 \times 10^{-8}$ & 379 & 83,858 & 3.90 \\
\hline
\end{tabular}


Table 5. Adsorption test data--Continued

\begin{tabular}{|c|c|c|c|c|c|}
\hline \multirow{2}{*}{$\begin{array}{l}\text { Test } \\
\text { number }\end{array}$} & \multicolumn{2}{|c|}{ Mole fraction $\mathrm{SF}_{6}$} & \multirow{2}{*}{$\begin{array}{l}\text { Test iength } \\
\text { (hours) }\end{array}$} & \multirow{2}{*}{$\begin{array}{l}\text { Total pressure } \\
(\mathrm{Pa})\end{array}$} & \multirow{2}{*}{$\begin{array}{l}\text { Sorption } \\
\text { (pmolg) }\end{array}$} \\
\hline & initlai & Finai & & & \\
\hline \multicolumn{6}{|c|}{$\begin{array}{l}\text { Topopah Spring Tuff, UZA } \\
150-250 \mu \mathrm{m}, 201 \text { grams-Continued }\end{array}$} \\
\hline TST4-5 & $1.00 \times 10^{-6}$ & $7.10 \times 10^{-7}$ & 42 & 81,459 & 28.1 \\
\hline TST4-6 & $1.00 \times 10^{-6}$ & $6.65 \times 10^{-7}$ & 66 & 83,058 & 33.1 \\
\hline TST4-7 & $1.00 \times 10^{-6}$ & $7.04 \times 10^{-7}$ & 88 & 83,192 & 29.3 \\
\hline TST4-8 & $1.00 \times 10^{-6}$ & $6.72 \times 10^{-7}$ & 112 & 83,592 & 32.6 \\
\hline TST4-9 & $1.94 \times 10^{-6}$ & $1.32 \times 10^{-6}$ & 66 & 81,459 & 59.9 \\
\hline TST4-10 & $1.94 \times 10^{-6}$ & $1.38 \times 10^{-6}$ & 65 & 81,725 & 54.0 \\
\hline TST4-11 & $1.94 \times 10^{-6}$ & $1.39 \times 10^{-6}$ & 91 & 87,191 & 57.5 \\
\hline \multicolumn{6}{|c|}{$\begin{array}{l}\text { Topopah Spring Tuff, UZ5 } \\
150-250 \mu \mathrm{m}, 199 \text { grams }\end{array}$} \\
\hline TST5-1 & $1.03 \times 10^{-7}$ & $6.43 \times 10^{-8}$ & 41 & 76,926 & 3.52 \\
\hline TST5-2 & $1.03 \times 10^{-7}$ & $6.15 \times 10^{-8}$ & 42 & 77,192 & 3.79 \\
\hline TST5-3 & $1.03 \times 10^{-7}$ & $6.50 \times 10^{-8}$ & 67 & 82,392 & 3.70 \\
\hline TST5-4 & $1.03 \times 10^{-7}$ & $5.64 \times 10^{-8}$ & 379 & 78,925 & 4.35 \\
\hline TST5-5 & $1.00 \times 10^{-6}$ & $6.43 \times 10^{-7}$ & 42 & 77,326 & 32.6 \\
\hline TST5-6 & $1.00 \times 10^{-6}$ & $6.45 \times 10^{-7}$ & 88 & 79,592 & 33.4 \\
\hline TST5-7 & $1.00 \times 10^{-6}$ & $6.30 \times 10^{-7}$ & 112 & 79,325 & 34.7 \\
\hline TST5-8 & $1.94 \times 10^{-6}$ & $1.31 \times 10^{-6}$ & 65 & 77,726 & 58.3 \\
\hline TST5-9 & $1.94 \times 10^{-6}$ & $1.24 \times 10^{-6}$ & 90 & 75,459 & 62.5 \\
\hline TST5-10 & $1.94 \times 10^{-6}$ & $1.34 \times 10^{-6}$ & 91 & 83,592 & 59.0 \\
\hline \multicolumn{6}{|c|}{$\begin{array}{l}\text { Gypsum cement } \\
63-150 \mu \mathrm{m}, 188 \text { grams }\end{array}$} \\
\hline GC-1 & $1.03 \times 10^{-7}$ & $1.005 \times 10^{-7}$ & 41 & 97,724 & 0.307 \\
\hline GC-2 & $1.03 \times 10^{-7}$ & $1.005 \times 10^{-7}$ & 67 & 100,123 & 0.314 \\
\hline GC-3 & $1.03 \times 10^{-7}$ & $1.005 \times 10^{-7}$ & 378 & 99,457 & 0.312 \\
\hline GC-4 & $1.00 \times 10^{-6}$ & $9.26 \times 10^{-7}$ & 43 & 98,523 & 9.15 \\
\hline GC-5 & $1.00 \times 10^{-6}$ & $9.04 \times 10^{-7}$ & 66 & 90,391 & 10.9 \\
\hline GC-6 & $1.00 \times 10^{-6}$ & $9.05 \times 10^{-7}$ & 88 & 88,791 & 10.6 \\
\hline GC-7 & $1.94 \times 10^{-6}$ & $1.79 \times 10^{-6}$ & 66 & 98,257 & 18.2 \\
\hline GC-8 & $1.94 \times 10^{-6}$ & $1.77 \times 10^{-6}$ & 90 & 97,724 & 20.5 \\
\hline \multicolumn{6}{|c|}{$\begin{array}{l}\text { Clinoptilolite } \\
150-250 \mu \mathrm{m}, 164 \text { grams }\end{array}$} \\
\hline CLINO-1 & $1.03 \times 10^{-7}$ & $6.40 \times 10^{-8}$ & 41 & 77,326 & 4.74 \\
\hline CLINO-2 & $1.03 \times 10^{-7}$ & $5.95 \times 10^{-8}$ & 42 & 77,726 & 5.31 \\
\hline CLINO-3 & $1.03 \times 10^{-7}$ & $6.33 \times 10^{-8}$ & 67 & 90,390 & 5.64 \\
\hline CLINO-4 & $1.03 \times 10^{-7}$ & $5.04 \times 10^{-8}$ & 379 & 90,258 & 7.46 \\
\hline CLINO-5 & $1.00 \times 10^{-6}$ & $6.14 \times 10^{-7}$ & 42 & 76,392 & 46.3 \\
\hline CLINO-6 & $1.00 \times 10^{-6}$ & $6.21 \times 10^{-7}$ & 66 & 82,525 & 49.1 \\
\hline CLINO-7 & $1.00 \times 10^{-6}$ & $6.77 \times 10^{-7}$ & 88 & 81,992 & 41.6 \\
\hline CLINO-8 & $1.00 \times 10^{-6}$ & $6.05 \times 10^{-7}$ & 112 & 83,592 & 51.9 \\
\hline CLINO-9 & $1.94 \times 10^{-6}$ & $1.28 \times 10^{-6}$ & 65 & 80,659 & 83.8 \\
\hline CLINO-10 & $1.94 \times 10^{-6}$ & $1.45 \times 10^{-6}$ & 90 & 84,658 & 64.9 \\
\hline CLINO-11 & $1.94 \times 10^{-6}$ & $1.18 \times 10^{-6}$ & 90 & 77,992 & 92.6 \\
\hline
\end{tabular}




$$
\begin{gathered}
V=V_{f}-V_{s} \\
V_{s}=\left(M \div \rho_{g}\right)(1-\Theta)
\end{gathered}
$$

where,

$$
\begin{aligned}
& V=\text { volume of gas injected, } \mathrm{m}^{3} ; \\
& V_{f}=\text { flask volume }, \mathrm{m}^{3} ; \\
& V_{s}=\text { sample volume }, \mathrm{m}^{3} ; \\
& M=\text { mass of sample }, \mathrm{g} ; \\
& \rho_{\mathrm{g}}=\text { grain density of the sample, } \mathrm{g} / \mathrm{m}^{3} ; \text { and } \\
& \Theta=\text { porosity of sample, dimensionless. }
\end{aligned}
$$

Due to the very small amount of $\mathrm{SF}_{6}$ that was adsorbed during a test, the volume of gas in the flask was assumed to be constant throughout the test.

In order to test whether the adsorption isotherms were independent of the amount of sorbent in the flask, experiments were conducted with $100-\mathrm{g}$ and $200-\mathrm{g}$ samples of bedded tuff and Topopah Spring Tuff, UZ4. The nearly identical adsorption isotherms for both the $100-\mathrm{g}$ and $200 \mathrm{-g}$ samples (fig. 7) demonstrated that the adsorption of $\mathrm{SF}_{6}$ is independent of the amount of sorbent in the flask.

\section{Analytical Instrument Calibration and Limits}

The gas samples collected from the flasks were analyzed using a Packard 439 gas chromatograph having a 6-foot by $1 / 8$-inch column of $80 / 100$ Porapak $Q$ at $35^{\circ} \mathrm{C}$, a nitrogen carrier gas flow of $30 \mathrm{~cm}^{3} / \mathrm{min}$, and an electron capture detector at $100^{\circ} \mathrm{C}$. The electron capture detector is capable of measuring $\mathrm{SF}_{6}$ at concentrations in the parts-per-trillion range (Clemons and Altschuller, 1966).

Calibration of the gas chromatograph was performed by analyzing National Institute of Standards and Technology certified standards before, during, and after a suite of samples was analyzed. The standards were chosen to span the range of concentration of the samples, and the analyses of each set of standards provided a calibration curve for the sample analyses. The range of squared correlation coefficients $\left(r^{2}\right)$ of the calibration curves was 0.96 to 1 .

\section{RESULTS OF SULFUR HEXAFLUORIDE ADSORPTION EXPERIMENTS}

The data collected during the adsorption experiments are shown in table 5, which lists the initial and final mole fraction of $\mathrm{SF}_{6}$ in the flask, the length of each test, the total gas pressure in the flask, and the amount of $\mathrm{SF}_{6}$ adsorbed onto the sample.
The amount of $\mathrm{SF}_{6}$ adsorbed from the flask atmosphere per gram of sample was:

$$
A=\frac{\left[(P)(V)\left(X_{S F 6 i}-X_{S F 6 f}\right)\right]}{(R)(T)(M)}
$$

where,

$$
\begin{aligned}
& A=\text { amount of } \mathrm{SF}_{6} \text { adsorbed, } \mathrm{mol} / \mathrm{g} ; \\
& P=\text { final gas pressure in flask, } \mathrm{Pa} ; \\
& V=\text { volume of gas injected, } \mathrm{m}^{3} ; \\
& R=\text { gas constant, } 8.314 \mathrm{~Pa} \cdot \mathrm{m}^{3} \cdot \mathrm{K}^{-1} \cdot \mathrm{mol}^{-1} ; \\
& T=\text { temperature, constant at } 293 \mathrm{~K} ; \\
& X_{\mathrm{SF} 6 i}=\text { initial mole fraction of } \mathrm{SF}_{6}, \text { dimensionless; } \\
& X_{\mathrm{SF} 6 f}=\text { final mole fraction of } \mathrm{SF}_{6}, \text { dimensionless; }
\end{aligned}
$$

and

$$
M=\text { grams of sample used in the experiment, } g \text {. }
$$

Of these values $R$ and $T$ are constants; $X_{\mathrm{SF} 6 i}$ was a known quantity; $V$ was calculated (equation 3); and $P$, $X_{\mathrm{SF} 6}$, and $M$ were measured.

\section{Adsorption Modeling}

The data from the adsorption experiment were modeled using the Freundlich isotherm equation and an empirical retention equation. The Freundlich isotherm equation was used to calculate distribution coefficients for each sample, while the retention equation describes the moles of $\mathrm{SF}_{6}$ adsorbed per square meter of surface area as a function of the partial pressure of $\mathrm{SF}_{6}$. Because the tests used crushed and dried tuffs, they provide data for modeling the maximum amount of $\mathrm{SF}_{6}$ that will be adsorbed onto the tuffs. In-situ adsorption will vary from the results of this experiment as a function of the core matrix and fracture permeability and moisture content of the rock or grout. In addition, these models are valid only for the range of $\mathrm{SF}_{6}$ concentrations actually tested.

\section{Freundlich Isotherm Equation}

The Freundlich isotherm equation (Freundlich, 1926) can be used for modeling adsorption of trace concentrations of sorbate onto substrates (Freeze and Cherry, 1979; Serne, 1992). For a linear isotherm, the Freundlich isotherm equation has the form:

$$
X=K_{d} C^{N} \text {, }
$$




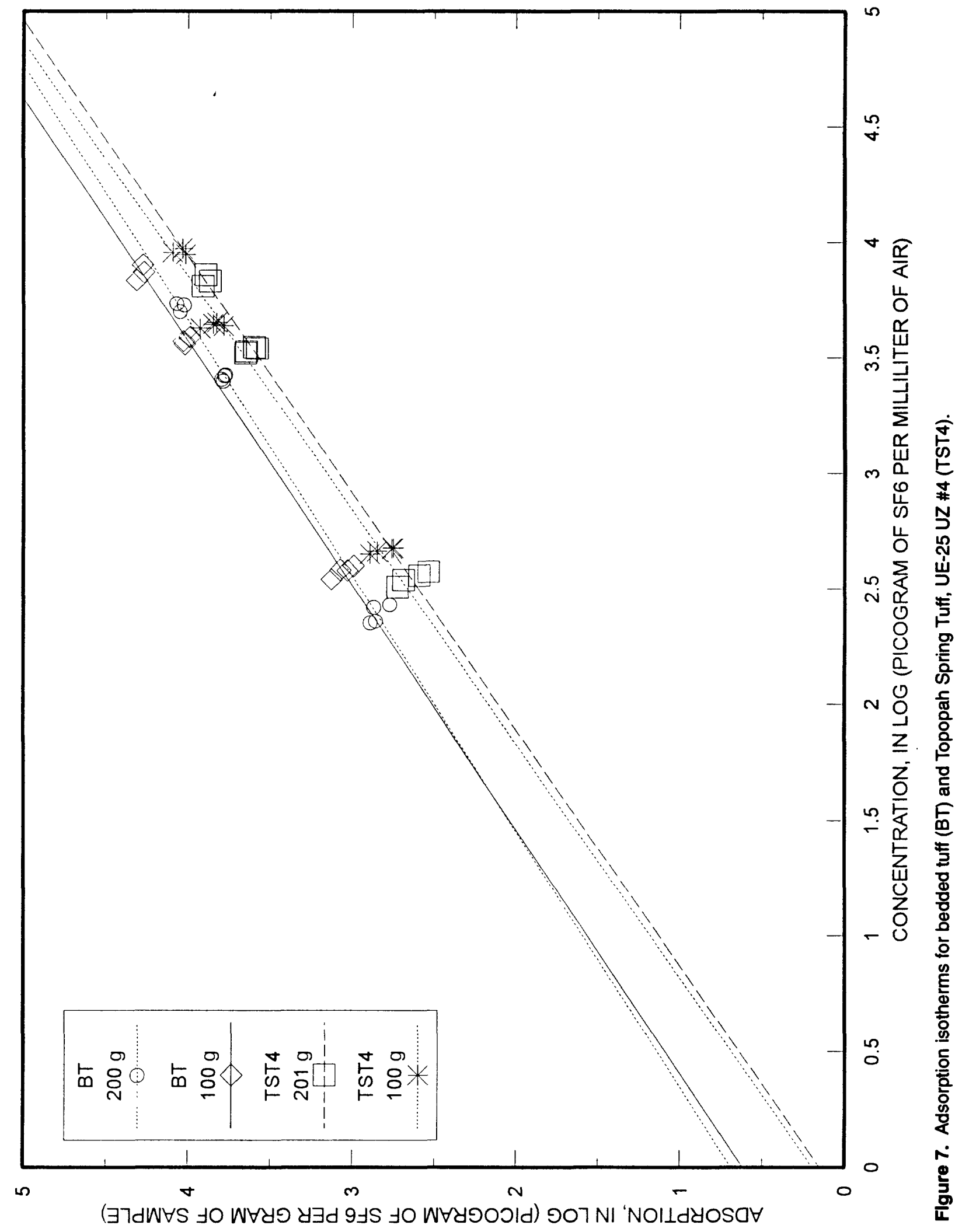


where,

$X$ = amount of sorbate adsorbed per mass of solid (pg/g; note the conversion of units from table 5, where sorption is in units of $(\mathrm{pmol} / \mathrm{g})$;

$C=$ sorbate concentration in solution $\left(\mathrm{pg} / \mathrm{cm}^{3}\right)$;

$K_{d}=$ distribution coefficient $\left(\mathrm{cm}^{3} / \mathrm{g}\right)$; and

$N=1$ (dimensionless; $N$ has a value other than 1 if the isotherm is not linear).

By taking the logarithms of both sides of equation (6), the Freundlich isotherm equation can be transformed to a linear equation:

$$
\log X=\log K_{d}+N \log C,
$$

where $N$ is the slope of the resulting line and $\log K_{d}$ is the y-intercept.

Values for $N$ were determined from linear regressions that were fit through the log-transformed data points for each sample (figs. 7-9). The slope $(N)$ varied between 0.87-1.04 (table 6) for all the samples except Tiva Canyon Tuff (1.69) and gypsum cement (1.50). Since $N$ is close to 1.0 for all but two of the samples, the linear form of the Freundlich isotherm equation was assumed to accurately represent the adsorption data. The distribution coefficients (table 6 ) determined for the samples decrease in the order of clinoptilolite $>$ BT $>$ TST5 > TST4 > YMT > PCT > TCT and GC. These distribution coefficient values show that $\mathrm{SF}_{6}$ is abundantly adsorbed onto clinoptilolite, bedded tuff, and Topopah Spring Tuff (UZ5); moderately adsorbed onto Topopah Spring Tuff (UZ4) and Yucca Mountain Tuff; but that it does not appreciably adsorb onto Pah Canyon Tuff, Tiva Canyon Tuff, or gypsum cement.

The data from tests started with $0.103 \mathrm{ppmv} \mathrm{SF}_{6}$ indicate that some of these tests may not have reached equilibrium. The data were corrected by using only the results that were collected from tests with a duration of 379 hours. This correction increased the distribution coefficient values of bedded tuff $(4.8 \rightarrow 8.0)$, Topopah Spring Tuff, UZ4 (1.5 $\rightarrow$ 3.4), Topopah Spring Tuff, UZ5 $(3.3 \rightarrow 6.1)$, and clinoptilolite $(6.2 \rightarrow 18)$.

Retardation factors (Freeze and Cherry, 1979; Fetter, 1994) were calculated for the dry, crushed tuffs from:

$$
R_{f}=1+\left(\rho_{\mathrm{b}} / \Theta\right) K_{d}
$$

where,

$R_{f}=$ retardation factor, dimensionless;

$\rho_{\mathrm{b}}=$ dry bulk density of the crushed tuff, $\mathrm{g} / \mathrm{cm}^{3}$;

$\Theta=$ porosity of the crushed tuff, dimensionless; and

$K_{d}=$ distribution coefficient, $\mathrm{cm}^{3} / \mathrm{g}$.
The average linear fluid velocity relative to the average velocity of a chemical species can be determined from the retardation equation:

$$
R_{f}=V_{x} / V_{c}
$$

where,

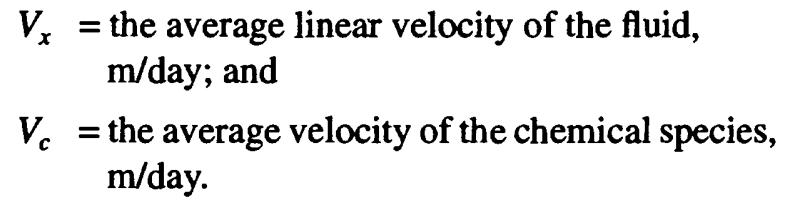

The relative velocity of the chemical species is determined by taking the reciprocal of the retardation factor:

$$
1 / R_{f}=V_{c} / V_{x}
$$

From the calculated relative velocities of $\mathrm{SF}_{6}$ for each tuff the percent retardation of $\mathrm{SF}_{6}$ could be determined. For instance, a tuff with a relative velocity of 0.33 would indicate that $\mathrm{SF}_{6}$ is retarded by 67 percent in that tuff. The retardation factors and relative velocities (table 7) calculated from the adsorption tests indicate that: (1) the Tiva Canyon Tuff and gypsum cement do not retard the transport of $\mathrm{SF}_{6}$; (2) the transport of $\mathrm{SF}_{6}$ through the Pah Canyon Tuff is retarded by 15-20 percent; and (3) the Yucca Mountain Tuff, bedded tuff, clinoptilolite, and Topopah Spring Tuff, UZA and 5 , retard the transport of $S_{6}$ by $60-90$ percent.

In order to approximate in-situ conditions more closely, the retardation equations were recalculated using the distribution coefficients and bulk densities of the crushed tuffs, and the grain densities of the original core samples (Loskot and Hammermeister, 1992) for porosity calculations. The retardation factors and relative velocities (table 8 ) calculated with the core samples show that: (1) the Tiva Canyon Tuff still does not retard the transport of $\mathrm{SF}_{6}$; (2) the transport of $\mathrm{SF}_{6}$ through the Pah Canyon Tuff is retarded by 33 percent; and (3) the Yucca Mountain Tuff, bedded tuff, clinoptilolite, and Topopah Spring Tuff, UZ4 and 5, retard the transport of $\mathrm{SF}_{6}$ by $75-96$ percent. The increased calculated sorptivity results directly from the decreased porosity (and decreased flow path) in the cores. If fracture flow is the dominant flow path in welded tuffs, then the retardation of sorbates may be diminished by the larger flow path available in the fractures. For partly saturated conditions, with an insoluble species like $\mathrm{SF}_{6}$, retardation would decrease even more because water will compete with the sorbate for available adsorption sites. 


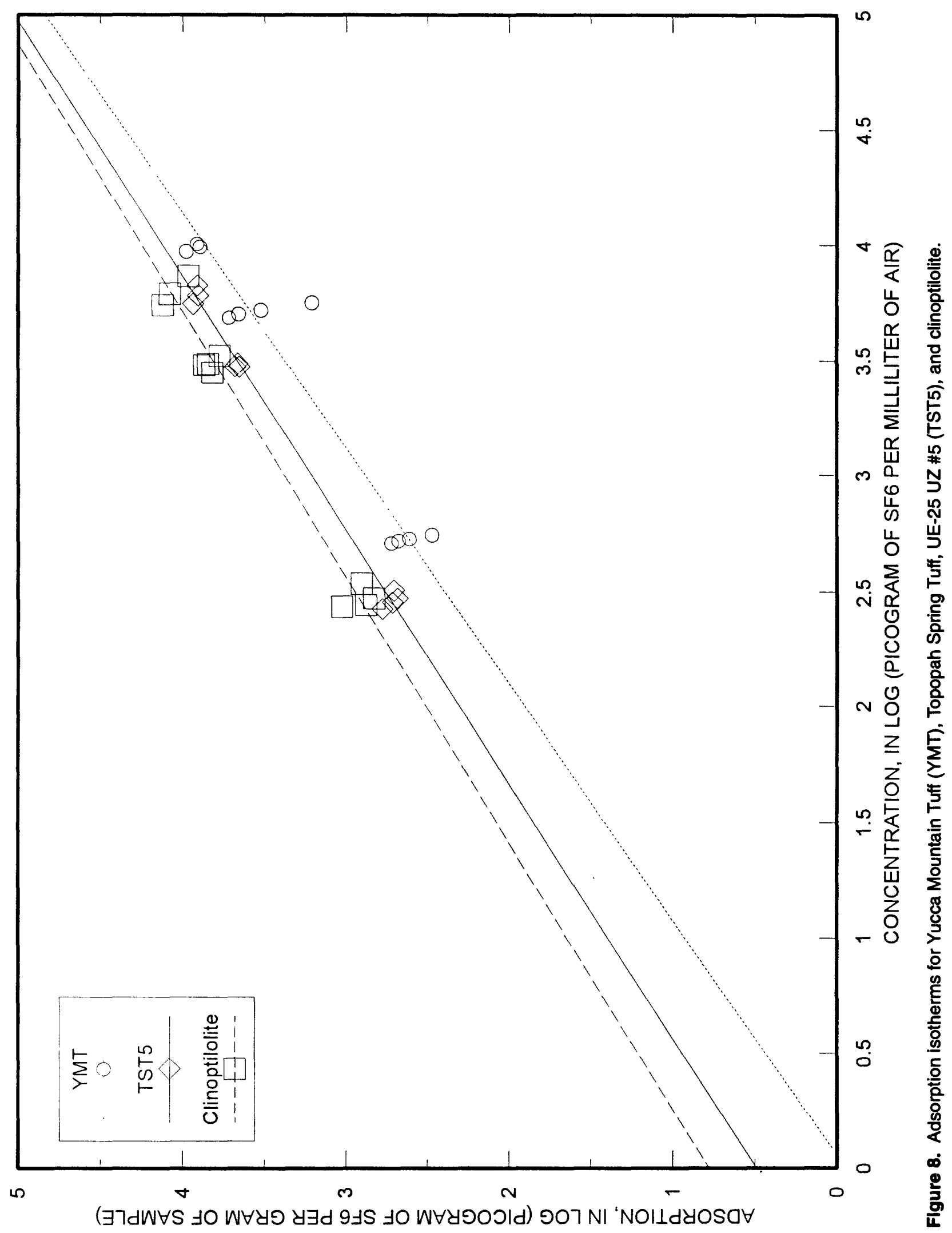




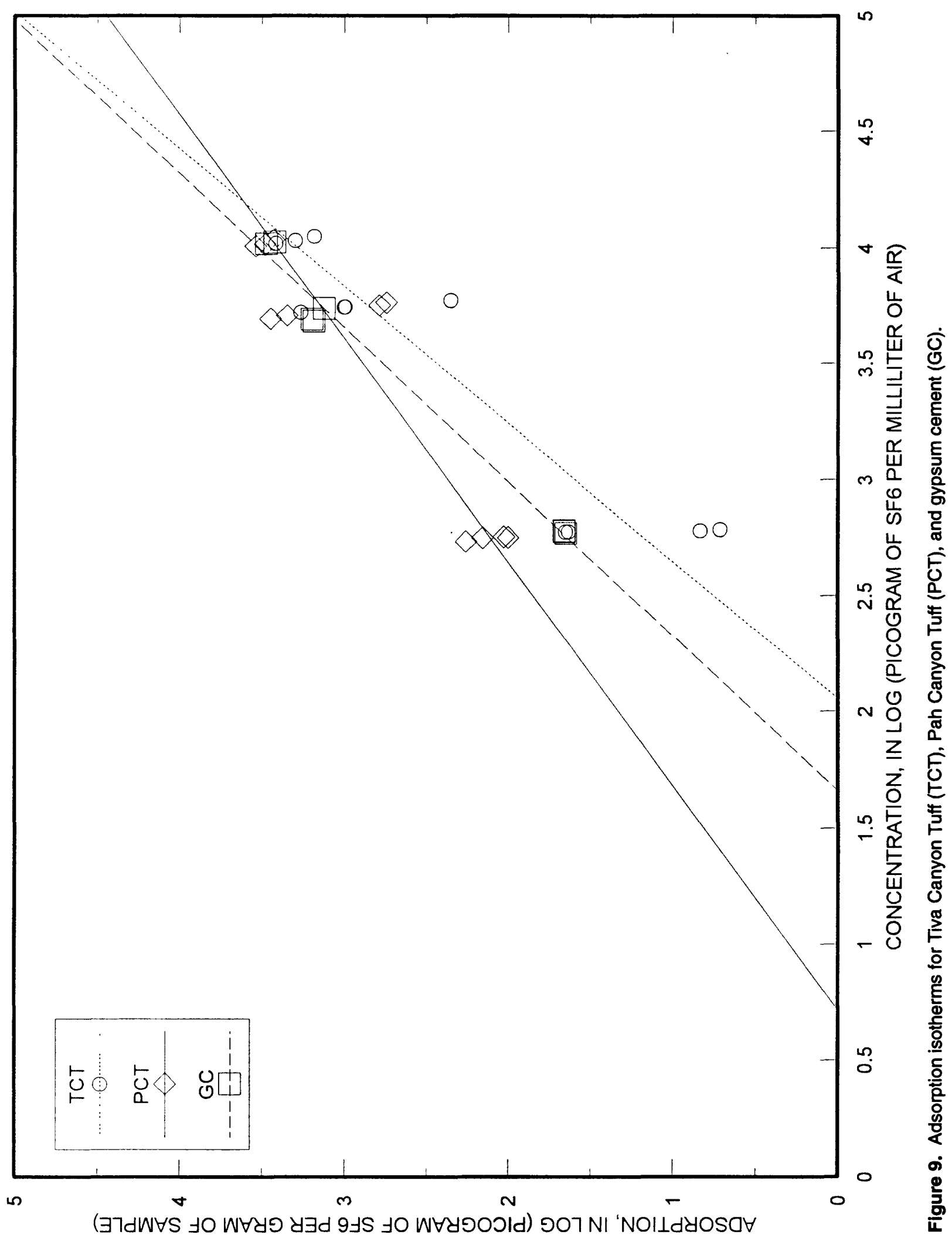


Table 6. Values for constants $\left(N, K_{d} K\right)$, squared correlation coefficients $\left(r^{2}\right)$, and standard error of estimate (SEE) for the Freundlich isotherm equations and the retention equations

[ $K_{d}$ is in units of cubic centimeters per gram, $\mathrm{cm}^{3} / \mathrm{g} ; K$ is in units of picomoles per meter squared per millipascal, $\mathrm{pmol} / \mathrm{m}^{2} \cdot \mathrm{mPa} ; N$ is the slope of the line determined by the adsorption isotherm; the correlation coefficients and the standard error of estimate are the same for both equations; $n$ is the number of experiments; --, no data]

\begin{tabular}{|c|c|c|c|c|c|c|}
\hline Sample & $\mathbf{n}$ & $N$ & $\kappa_{d}$ & $\kappa$ & $r^{2}$ & SEE \\
\hline $\mathrm{TCT}^{1} 150-250$ & 11 & 1.69 & 0.0004 & 0.003 & 0.87 & 0.39 \\
\hline YMT 150-250 & 11 & 0.98 & 0.90 & 0.037 & 0.92 & 0.18 \\
\hline PCT $150-250$ & 11 & 1.04 & 0.19 & 0.017 & 0.86 & 0.25 \\
\hline $\begin{array}{l}\text { BT } 150-250 \\
200 \text { grams }\end{array}$ & 11 & 0.90 & 5.5 & 0.064 & 0.99 & 0.05 \\
\hline $\begin{array}{l}\text { BT } 150-250 \\
100 \text { grams }\end{array}$ & 11 & 0.95 & 4.4 & 0.061 & 0.99 & 0.06 \\
\hline Combined BT & 22 & 0.93 & 4.8 & 0.062 & 0.99 & 0.06 \\
\hline $\begin{array}{l}\text { TST4 150-250 } \\
201 \text { grams }\end{array}$ & 11 & 0.98 & 1.5 & 0.068 & 0.98 & 0.07 \\
\hline $\begin{array}{l}\text { TST4 } 150-250 \\
100 \text { grams }\end{array}$ & 11 & 0.99 & 1.6 & 0.075 & 0.98 & 0.08 \\
\hline Combined TST4 & 22 & 0.99 & 1.5 & 0.070 & 0.98 & 0.08 \\
\hline TST5 $150-250$ & 10 & 0.91 & 3.3 & 0.038 & 0.99 & 0.05 \\
\hline GC $63-150$ & 8 & 1.50 & 0.003 & 0.002 & 0.99 & 0.10 \\
\hline CLINO 150-250 & 11 & 0.87 & 6.2 & 0.120 & 0.97 & 0.10 \\
\hline Tuffs $^{2}$ & 76 & 0.94 & -- & 0.050 & 0.86 & 0.23 \\
\hline
\end{tabular}

${ }^{1}$ Refer to table 2 for explanation of sample labels.

${ }^{2}$ Does not include TCT. 
Table 7. Values for variables in the retardation equation

$\left[\rho_{b}\right.$, bulk density in grams per cubic centimeter, $g / \mathrm{cm}^{3} ; \Theta$, porosity, dimensionless; $\boldsymbol{K}_{d}$, distribution coefficient in cubic centimeters per gram, $\mathrm{cm}^{3} / \mathrm{g} ; R_{f}$ retardation factor, dimension-less; $V_{c}$, average velocity of the chemical species in meters per day, $\mathrm{m} /$ day; $V_{x}$ average linear velocity of the fluid in meters per day, $\mathrm{m} /$ day]

\begin{tabular}{|c|c|c|c|c|}
\hline Sample & $\underset{\left(g^{\prime} / \mathrm{cm}^{3}\right)}{\rho_{b} \theta}$ & $\underset{\left(\mathrm{cm}^{3} / \mathrm{g}\right)}{\kappa_{g}}$ & $\boldsymbol{R}_{\boldsymbol{f}}$ & $V_{c} N_{x}$ \\
\hline TCT $^{1} 150-250$ & 1.72 & 0.0004 & 1.0007 & 1.0 \\
\hline YMT 150-250 & 1.55 & 0.90 & 2.4 & 0.42 \\
\hline PCT $150-250$ & 1.13 & 0.19 & 1.2 & 0.83 \\
\hline Combined BT & 0.99 & 4.8 & 5.8 & 0.17 \\
\hline Combined TST4 & 1.30 & 1.5 & 3.0 & 0.33 \\
\hline TST5 150-250 & 1.30 & 3.3 & 5.3 & 0.19 \\
\hline GC 63-150 & 1.30 & 0.003 & 1.004 & 1.0 \\
\hline CLINO $150-250$ & 1.40 & 6.2 & 9.7 & 0.10 \\
\hline
\end{tabular}

Table 8. Values of variables ${ }^{1}$ in the retardation equation using bulk and grain densities ${ }^{2}$ (for porosity calculations) of core samples

\begin{tabular}{|c|c|c|c|c|}
\hline $\begin{array}{c}\text { Core } \\
\text { sample }\end{array}$ & $\begin{array}{c}\rho_{b} \theta \\
\left(g^{\prime} / \mathrm{cm}^{3}\right)\end{array}$ & $\underset{\left(\mathrm{cm}^{3} / \mathrm{g}\right)}{K_{f}}$ & $A_{f}$ & $V_{d} N_{x}$ \\
\hline $\mathrm{TCT}^{3}$ & 18 & 0.0004 & 1.007 & 0.99 \\
\hline YMT & 3.3 & 0.90 & 4.0 & 0.25 \\
\hline PCT & 2.4 & 0.19 & 1.5 & 0.67 \\
\hline BT & 2.3 & 4.8 & 12 & 0.08 \\
\hline TST4 & 18 & 1.5 & 28 & 0.04 \\
\hline TST5 & 2.8 & 3.3 & 10 & 0.10 \\
\hline
\end{tabular}

\section{Retention Equation}

The retention equation has the same form as the Freundlich isotherm equation (equation 6):

$$
X=K C^{N} \text {, }
$$

but,

$$
\begin{aligned}
X= & \text { picomoles of sorbate adsorbed per meter } \\
& \text { squared of sorbent }\left(\mathrm{pmol} / \mathrm{m}^{2}\right) ; \\
C= & \text { partial pressure of sorbate }(\mathrm{mPa}) ; \\
K= & \text { constant }\left(\mathrm{pmol} / \mathrm{m}^{2} \cdot \mathrm{mPa}\right) ; \text { and } \\
N= & \text { constant (dimensionless) }
\end{aligned}
$$

Because the tuffs have similar values for the constants $N$ and $K$, a retention equation was determined for the combined data from all of the tuffs (except the Tiva Canyon Tuff) (fig. 10, table 6). The combined equation is:

$$
X=0.047 C^{0.95}
$$

After correcting for the incomplete adsorption of some of the tests (see above), the equation changes to:

$$
X=0.067 C^{0.87}
$$

These two equations are plotted in figure 11 over the concentration range of $\mathrm{SF}_{6}$ used in the adsorption tests. At concentrations of 40 millipascals $(\mathrm{mPa})$ of $\mathrm{SF}_{6}$ the values of $X$ between the two equations vary by 6 percent. The percentage difference between the two equations approaches zero at either end of the concentration range tested.

The retention equations can be used to predict the amount of $\mathrm{SF}_{6}$ that the tuffs will adsorb if the equilibrium concentration of $\mathrm{SF}_{6}$ is known or specified. The calculated value of $X$, determined from either the combined or individual retention equations, must be multiplied by the measured surface area of the appropriate tuff to give the predicted adsorption capacity of that tuff. The predicted adsorption capacities of the tuffs, calculated for both the combined and individual retention equations, and assuming that the tuffs were in equilibrium with air containing $100 \mathrm{mPa}$ of $\mathrm{SF}_{6}$, are shown in table 9 . The combined equation closely predicts the adsorption capacity for the Tiva Canyon Tuff, Yucca Mountain Tuff, and bedded tuff, but predicts too much adsorption for the Topopah Spring Tuff, UZ5, and Pah Canyon Tuff and too little adsorption for the Topopah Spring Tuff, UZA (fig. 10, table 9).

The adsorption of $\mathrm{SF}_{6}$ onto tuff is proportional to the surface area of the tuff (figure 10 and 11) and appears to be a function of the percent of zeolite in the tuff (fig. 12). Zeolites are secondary minerals in tuffs, so the degree of alteration that a tuff has undergone will affect the ability of that tuff to adsorb chemical species. 


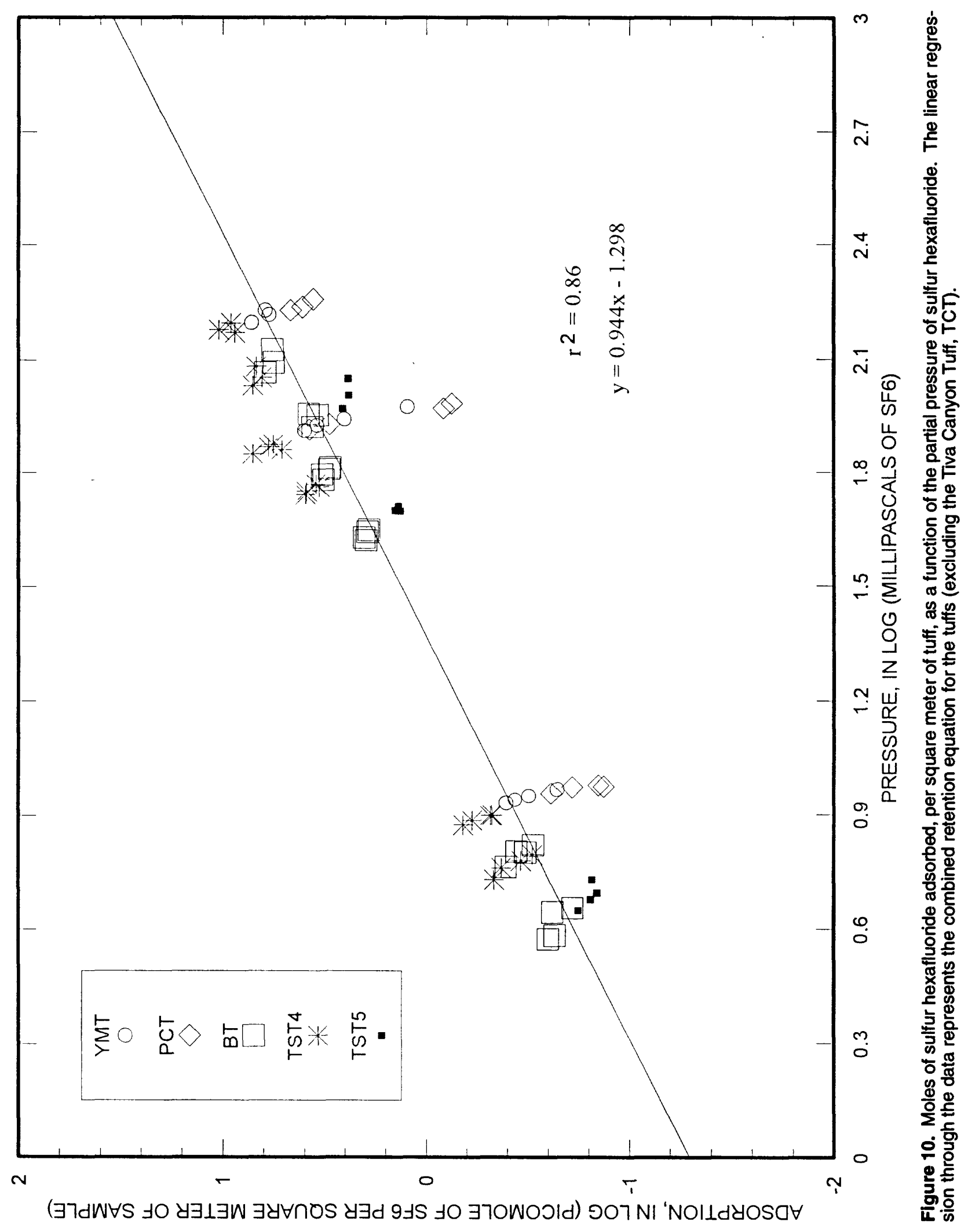




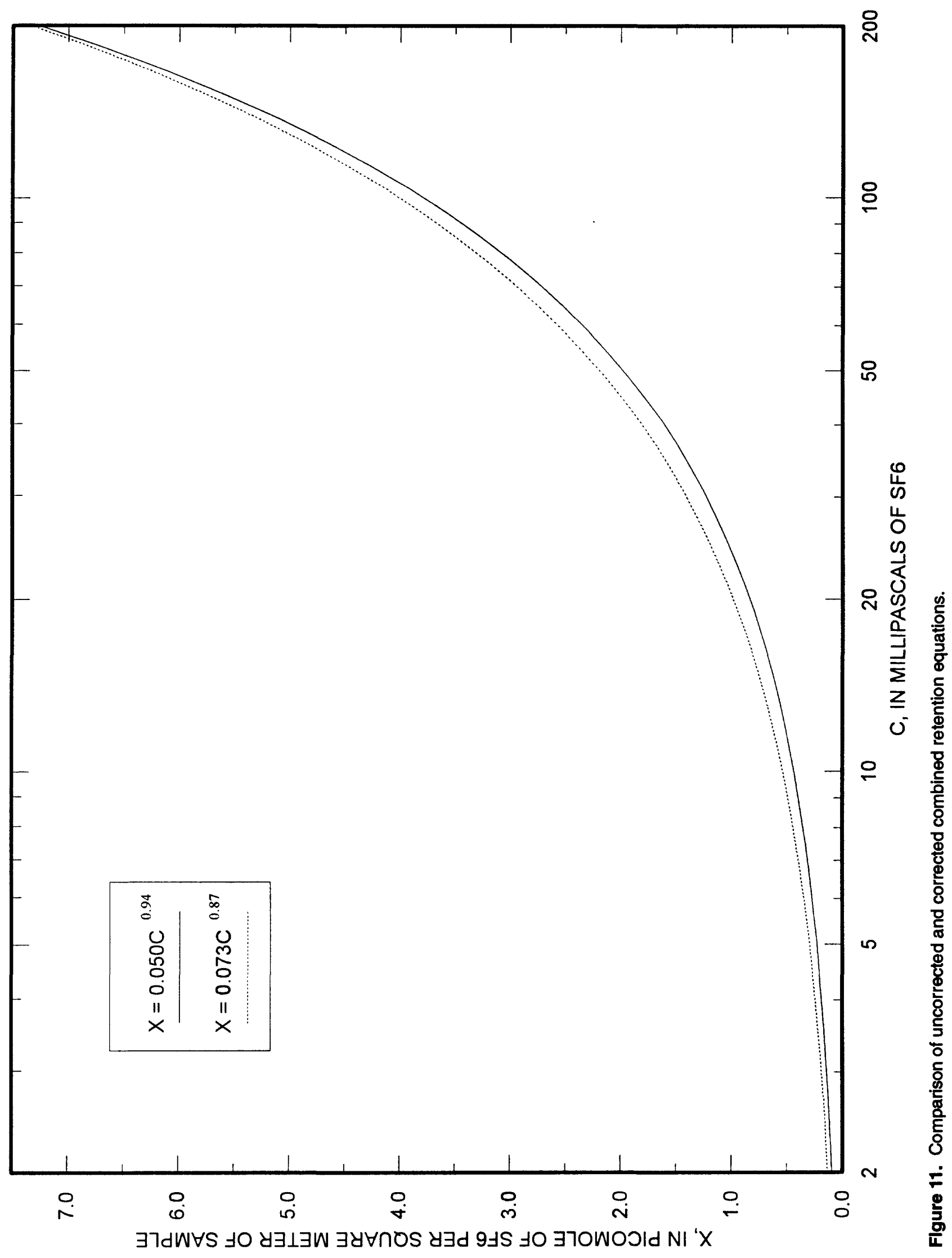




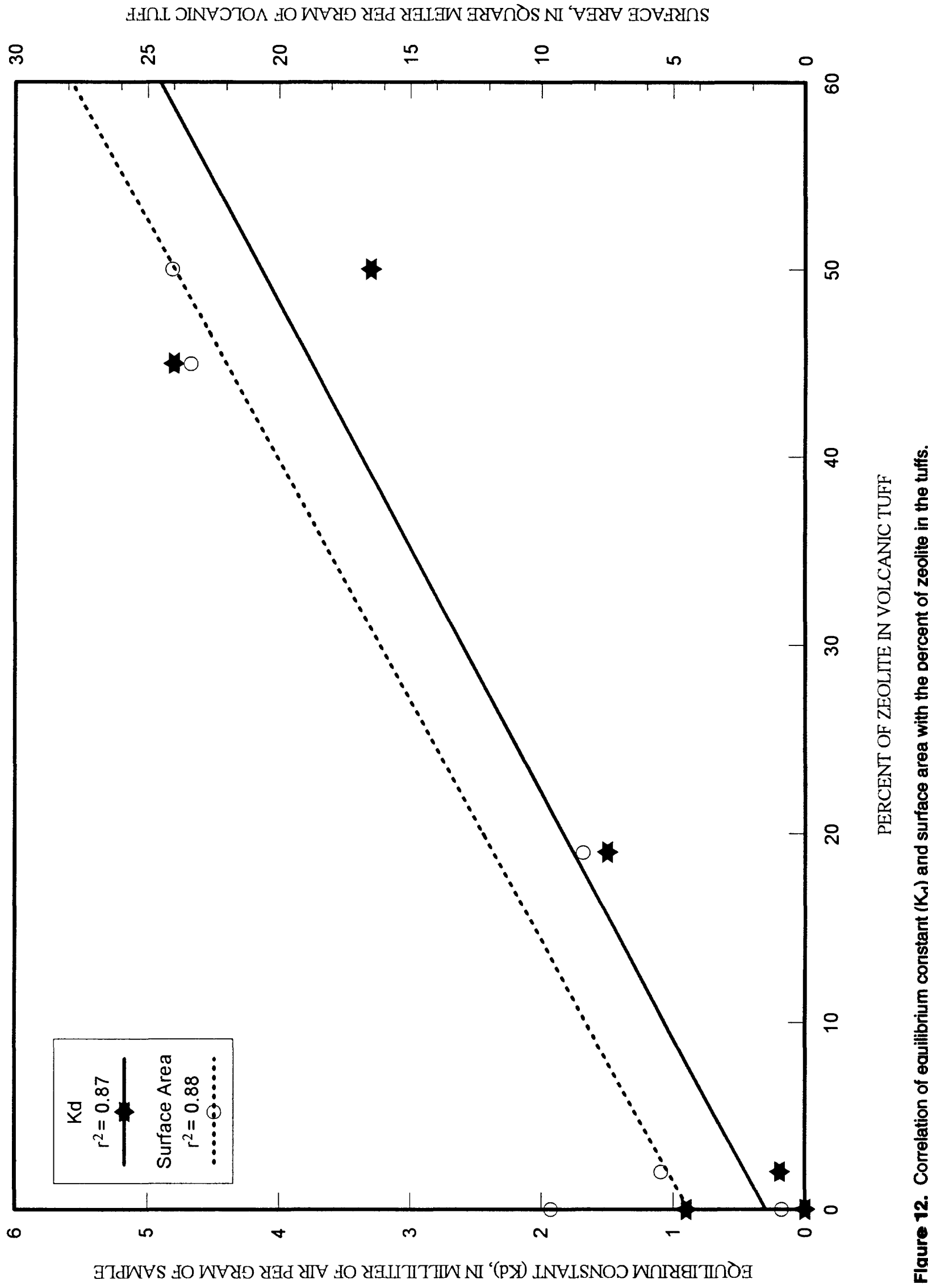


Table 9. Predicted adsorption of sulfur hexafluoride ( $\mathrm{pmol}$ SFe $/$ tuff $_{\text {ti }}$ ) onto tuffs using the combined and individual retention equations

[The amount of adsorption was calculated for tuff in equilibrium with air containing 100 mpascals of $\mathrm{SF}_{6} ; \mathrm{pmol} / \mathrm{g}$, picomoles per gram]

\begin{tabular}{ccc}
\hline Sample & $\begin{array}{c}\text { Adsorption } \\
\text { comblned equation } \\
\text { (pmoVg) }\end{array}$ & $\begin{array}{c}\text { Adsorption } \\
\text { individuai equation } \\
\text { (pmoVg) }\end{array}$ \\
\hline TCT $^{1}$ 150-250 & 3.1 & 5.8 \\
YMT 150-250 & 35 & 31 \\
PCT 150-250 & 20 & 11 \\
Combined BT & 90 & 110 \\
Combined TST4 & 32 & 56 \\
TST5 150-250 & 92 & 61 \\
\hline${ }^{1}$ Refer to table 2 for explanation of sample labels.
\end{tabular}

This is demonstrated by the Topopah Spring Tuff samples, where the welded sample from UZ4 has undergone less alteration than the nonwelded sample from UZ5, and consequently, contains less zeolite and has less sorptive capacity.

\section{CONCLUSIONS}

The adsorption experiment demonstrates that $\mathrm{SF}_{6}$ does not always behave conservatively. Although $\mathrm{SF}_{6}$ approximates conservative behavior $\left(K_{d} \approx 0\right)$ when in contact with the Tiva Canyon Tuff and gypsum cement, it is slightly adsorbed by the Pah Canyon Tuff and strongly adsorbed $\left(K_{d}>0.9\right)$ by the Yucca Mountain Tuff, bedded tuff, and the Topopah Spring Tuff, UZ4 and UZ5. This adsorption will cause retardation of transport in these unsaturated zone materials, resulting in slower observed velocities than would be predicted from modeling of conservative tracer behavior.

The combined retention equation provides a direct means of predicting the amount of $\mathrm{SF}_{6}$ that may be adsorbed by tuffs with a known surface area, and a general application of the combined retention equation may be valid for estimating the sorptive capacity of any unsaturated zone silicates for $\mathrm{SF}_{6}$. The surface area of a material can be used to estimate the equilibrium adsorption constant (fig. 12) of the material, allowing a prediction of the relative transport velocity of $\mathrm{SF}_{6}$ through the material by using the retardation equation (equation 8).

\section{REFERENCES}

Bish, D.L., 1990, Long-term stability of clinoptilolite-The development of a " $B$ " phase: European Journal of Mineralogy, v. 2, no. 6, p. 771-777.

Carroll-Webb, S.A., and Walther, J.V., 1988, A surface complex reaction model for the $\mathrm{pH}$-dependence of corundum and kaolinite dissolution rates: Geochimica et Cosmochimica Acta, v. 52, p. 2609-2623.

Clemons, C.A., and Altschuller, A.P., 1966, Responses of electron-capture detector to halogenated substances: Analytical Chemistry, v. 38, no. 1, p. 133-136.

Dayal, Ramesh, and Klein, R., 1988, $\mathrm{CO}_{2} /$ Grout interactions and their relevance to ${ }^{14} \mathrm{C}$ attenuation in cementitious backfill materials: Radiochimica Acta, v. 44/45, pt. 2 , p. 263-270.

Fetter, C.W., 1994, Applied hydrogeology (3d ed.): New York, Macmillan College Publishing Company, 691 p.

Flint, L.E., and Flint, A.L., 1990, Preliminary permeability and water-retention data for nonwelded and bedded tuff samples, Yucca Mountain area, Nye County, Nevada: U.S. Geological Survey Open-File Report 90-569, 57 p.

Flint, A.L., Flint, L.E., and Hevesi, J.A., 1993, The influence of long-term climate change on net infiltration at Yucca Mountain, Nevada, in Proceedings of the Fourth International Conference on High Level Radioactive Waste Management, Las Vegas, Nevada, 1993: La Grange Park, Illinois, American Nuclear Society, Inc., and New York, American Society of Civil Engineers, p. 732-737.

Freeze, R.A., and Cherry, J.A., 1979, Groundwater: Englewood Cliffs, N.J., Prentice-Hall, 604 p.

Freundlich, Herbert, 1926, Colloid and capillary chemistry: New York, Dutton, 883 p.

Houston, S.L., and others, 1989, A batch-type testing method for determination of adsorption of gaseous compounds on partially saturated soils: Geotechnical Testing Journal, v. 12, no. 1, p. 3-10.

Klug, H.P., and Alexander, L.E., 1974, X-ray diffraction procedures for polycrystalline and amorphous materials (2d ed.): New York, John Wiley and Sons, 966 p.

Knowlton, G.D., White, T.R., and Mckague, H.L., 1981, Thermal study of types of water associated with clinoptilolite: Clays and Clay Minerals, v. 29, p. 403-411.

Kreamer, D.K., Weeks, E.P., and Thompson, G.M., 1988, A field technique to measure the tortuosity and sorptionaffected porosity for gaseous diffusion of materials in the unsaturated zone with experimental results from near Barnwell, South Carolina: Water Resources Research, v. 24, no. 3, p. 331-341. 
Lewis-Russ, Anne, 1990, Borate adsorption by some tuffs: Evaluation of borate as a potential tracer for unsaturated flow at Yucca Mountain: Golden, Colorado School of Mines, Ph.D. dissertation, 365 p.

Loskot, C.L., and Hammermeister, D.P., 1992, Geohydrologic data from test holes UE-25 UZ \#4 and UE-25 UZ \#5, Yucca Mountain Area, Nye County, Nevada: U.S. Geological Survey Open-File Report 90-369, 56 p.

Ming, W.M., and Mumpton, F.A., 1989, Zeolites in soils, in Dixon, J.B., and Weed, S.B., eds., Minerals in soil environments (2d ed.): Madison, Wisconsin, Soil Science Society of America, p. 873-911.

Sawyer, D.A., and others, 1994, Episodic caldera volcanism in the Miocene southwestern Nevada volcanic field: Revised stratigraphic framework, ${ }^{40} \mathrm{Ar} /{ }^{39} \mathrm{Ar}$ geochronology, and implications for magnetism and extension: Geological Society of America Bulletin, v. 106, p. 1304-1318.

Scott, R.B., and Bonk, J., 1984, Preliminary geologic map of Yucca Mountain with geologic sections, Nye County, Nevada: U.S. Geological Survey Open-File Report 84-494, 9 p., scale 1:12,000.

Serne, R.J., 1992, Current adsorption models and open issues pertaining to performance assessment: Los Alamos National Laboratory Report LA-12325-C, p. 43-74.
Sheppard, R.A., and Gude, A.J., 1982, Mineralogy, chemistry, gas adsorption, and $\mathrm{NH}_{4}$ +-exchange capacity for selected zeolitic tuffs from the western United States: U.S. Geological Survey Open-File Report 82-969, 16 p.

Thomas, K.W., 1987, Summary of sorption measurements performed with Yucca Mountain, Nevada, tuff samples and water from well J-13: Los Alamos National Laboratory Report LA-10960-MS, 32 p.

Vaniman, D., and others, 1984, Variations in authigenic mineralogy and sorptive zeolite abundance at Yucca Mountain, Nevada, based on studies of drill cores USW GU-3 and G-3: Los Alamos National Laboratory Report LA-9707-MS, 71 p.

Yang, I.C., 1992, Flow and transport through unsaturated rock-Data from two test holes, Yucca Mountain, Nevada, in Proceedings of the Third International Conference on High Level Radioactive Waste Management, Las Vegas, Nevada, 1992: La Grange Park, Illinois, American Nuclear Society, Inc., and New York, American Society of Civil Engineers, p. 732-737.

Yang, I.C., Turner, A.K., Sayre, T.M., and Montazer, Parviz, 1988, Triaxial-compression of pore water from unsaturated tuff, Yucca Mountain, Nevada: U.S. Geological Survey Water-Resources Investigations Report 88-4189, 68 p. 